\title{
THE CHEMICAL AND PHYSICAL PROPERTIES OF CONDENSED PHOSPHATES
}

\author{
EDWARD J. GRIFFITH
}

Monsanto Company, St Louis, Missouri, USA

\begin{abstract}
In the following work the current status of inorganic phosphate chemistry is discussed briefly. The influence of phase transitions upon the physical properties of condensed phosphates is reviewed and new data for the $54^{\circ} \mathrm{C}$ transition of $\mathrm{Na}_{4} \mathrm{P}_{4} \mathrm{O}_{12} \cdot 4 \mathrm{H}_{2} \mathrm{O}$ are presented.

Urea will prevent the decomposition of $\mathrm{Na}_{5} \mathrm{P}_{3} \mathrm{O}_{10}$ during the transition of $\mathrm{Na}_{5} \mathrm{P}_{3} \mathrm{O}_{10} \cdot 6 \mathrm{H}_{2} \mathrm{O}$ to $\mathrm{Na}_{5} \mathrm{P}_{3} \mathrm{O}_{10}$. The mechanism of this action is discussed.

The growths of cleavage families resulting from the hydrolytic degradation of condensed phosphates are discussed, and published rate constants are employed to calculate the growth of families of phosphates.
\end{abstract}

\section{INTRODUCTION}

A number of comprehensive reviews of modern inorganic phosphate chemistry have been published ${ }^{1-14,82,83}$. Few, if any, important segments of fundamental phosphate chemistry have been ignored.

During the last three decades, condensed phosphate chemistry has evolved from an unpredictable collection of inconsistencies into a relatively mature science. Methods are available to isolate and definitely identify almost any phosphate structure capable of existence. The modern literature, unlike the older literature, contains few claims to new phosphate structures which have in reality never been prepared.

To attempt to re-review the well established background literature would be superfluous, but a few of the landmark works of the last decade will be mentioned. One of the more noteworthy accomplishments was the isolation and crystallization of pentameta- ${ }^{16}$, hexameta- ${ }^{15-17}$, and octametaphosphates ${ }^{15,18}$. The extensive series of three-component phase diagrams of metaphosphates ${ }^{14,85-109}$; the thermodynamic properties of condensed phosphates ${ }^{19-21,77-78}$; the use of new highly effective condensation agents ${ }^{22}$, ${ }_{79}$; the hydrolytic degradation of intermediate chain length phosphates ${ }^{23,81}$; the introduction of gel chromatography ${ }^{24}$; phosphate distribution studies ${ }^{25}$,' 115,116 ; the detailed studies of the dehydration of triphosphate hydrates ${ }^{58-74}$; the three-component aqueous phase diagrams of condensed phosphates ${ }^{26,84}$; the electrical conductivity of phosphate melt systems ${ }^{27}$; and the proof of the non-existence of isophosphates in Langheld $\operatorname{ester}^{28}$ are but a few of the many important works of the last decade. Most of the advances in inorganic condensed phosphate chemistry during the last decade have occurred in Europe, Russia and Japan. 
In general, the major portion of condensed phosphate research continues to be applied research as opposed to fundamental research. Nomenclature continues to be a source of confusion, particularly for the metaphosphates. Compositions called 'hexametaphosphate' are common and often it is impossible to determine the nature of a phosphate from its description in the literature. Most other ring phosphates are properly named, but the name metaphosphate is still used to describe long chain polyphosphates.

The ultraphosphates are being mentioned more frequently in the current literature $22,79,110-114$. This fertile region contains compositions potentially more useful than the polyphosphate glasses and should be explored in greater detail during the next decade.

Several areas deserve more attention than they have received. The three component $\mathrm{M}_{2} \mathrm{O}-\mathrm{M}_{2}^{\prime} \mathrm{O}-\mathrm{P}_{2} \mathrm{O}_{5}$ phase systems should contain stable polyphosphates in the penta- to decaphosphate range. The current known methods of preparing these polyphosphate salts are not satisfactory. Some work has been done toward relating the size of a cation to the type of phosphate which can be crystallized from a melt ${ }^{2,80}$. More work is needed in this area. The existing phase diagrams seem to indicate that compounds containing an even number of phosphorus atoms crystallize more easily from a melt than do compounds which contain odd numbers of phosphorus atoms.

Physical studies of melt systems, particularly electrical conductivity and viscosity, should be determined for a wider variety of melt systems. Quenching studies indicate that the potassium system is not as similar to the sodium or hydrogen systems as might be anticipated.

New methods of directive synthesis of poly- and metaphosphates similar to the synthetic methods of organic chemistry are needed, and additional work in inert melt systems and non-aqueous solvents will be fruitful.

\section{EXPERIMENTAL}

The following report deals with several diverse chemical and physical properties of condensed phosphates. Two of the studies involve phase transitions of phosphate systems. Two of the studies investigate the use of urea as a dehydrating agent, and one study treats the hydrolytic degradation of tetra-. penta-, hexa-, hepta- and octaphosphates as cleavage families.

\section{Physical and chemical properties}

The physical and chemical properties of condensed phosphates depend upon the following variables: (1) the $\mathrm{M}_{2} \mathrm{O}-\mathrm{P}_{2} \mathrm{O}_{5}$ ratio of the molecules, (2) the structure of the molecules, (3) the size of the molecules, (4) the counter cations associated with the phosphate anions, and (5) the thermal history of the phosphate. The phase state of a specific phosphate will be determined by the thermal history of the phosphate if pressure and composition are not variables. A single phosphate composition may exhibit a wide spectrum of useful properties as a result of phase transitions. Additional new properties could be achieved if pressure as well as temperature and composition were treated as variables. Thus far little or no work has been done in this interesting area. 


\section{Meta- and polyphosphates}

The phosphates have been employed in a large number of practical applications, while the ring phosphates have been used very little. The functional differences in the two systems are a result of the symmetry of the molecules. The metaphosphate rings exhibit well defined specific properties. Their functional groups are all similar in behaviour and respond to change in their environment in a similar manner. All known metaphosphate ring systems can be easily crystallized as stable alkali metal salts.

The polyphosphates, conver'sely, are highly unsymmetrical in both structure and property. There are few environments in which the two ends of the chain function similarly, and no condition under which all functional groups are similar. As the molecules increase in complexity, the range of functional responses also increases until the molecules become so large as to cause the differences to become indistinguishably small, and the individual behaviour of a single group is lost. It is to be expected that a pentaphosphate should exhibit a much wider range of properties than a di- or triphosphate, but a phosphate of 35 phosphorus atoms is very similar to a phosphate of 36 phosphorus atoms, etc. The low molecular weight polyphosphates and the very high molecular weight polyphosphates can be easily crystallized as the alkali metal salts, but the polyphosphates with a large diversity of properties in the intermediate size range have never been crystallized as the alkali metal salts.

The above observations are summarized when it is noted that condensed phosphates which exhibit simple first order n.m.r. spectra are easily crystallized, while those which exhibit complex spectra are difficult or impossible to crystallize as simple alkali metal salts.

\section{Phase transition}

Phase transitions are classified in thermodynamic treatments as continuous and discontinuous ${ }^{29}$. In the former case, the transitions may occur through an intermediate hybrid crystal. In the latter case, the mother crystal is decomposed into daughter crystals which may or may not be sirnilar to the mother crystal. In the discontinuous transitions, the curve for heat capacity versus temperature discontinuous at some interval of a transition.

In a physical sense, a great variety of phase transitions occur in phosphate systems. In the following discussion the transitions are classified according to structural changes in the systems rather than by thermodynamic considerations. Most of the condensed phosphate transitions are probably of the discontinuous type.

A phosphate system may undergo a transition in which the integrity of the phosphate anion is not violated. A typical example is the transition of Form II sodium triphosphate into Form I sodium triphosphate. A second type of transition may occur in which the phosphate molecule undergoing the transition is completely destroyed, and not only are new daughter crystals formed, but a totally new anion is formed. Transitions of this type are the conversion of Maddrell's salt into sodium trimetaphosphate, or the conversion of crystalline sodium hexametaphosphate into trimetaphosphate 
upon heating. Transitions of this type are relatively rare in systems other than phosphates, silicates and similar polyanion systems.

A third type of transition occurs at the incongruent melting point of several polyphosphates. In these transitions a second phosphate anion and a melt are formed. All known intermediate chain length polyphosphates formed as phase diagram entities are of this type ${ }^{30-32}$.

Yet another type of transformation occurs during the dehydration of a crystalline hydrate. In most systems the phosphate anion is dehydrated without degradation, while in other systems the phosphate anion is destroyed ${ }^{33}$. Examples of salts which dehydrate without degradation are $\mathrm{Na}_{4} \mathrm{P}_{2} \mathrm{O}_{7} \cdot 10 \mathrm{H}_{2} \mathrm{O}$, $\mathrm{Na}_{4} \mathrm{P}_{4} \mathrm{O}_{12} \cdot 4 \mathrm{H}_{2} \mathrm{O}$ and $\mathrm{Na}_{3} \mathrm{P}_{3} \mathrm{O}_{9} \cdot 6 \mathrm{H}_{2} \mathrm{O}$. Conversely, examples of salts which do suffer anion degradation during dehydration are $\mathrm{Na}_{5} \mathrm{P}_{3} \mathrm{O}_{10} \cdot 6 \mathrm{H}_{2} \mathrm{O}^{33}$ and $\mathrm{Na}_{3} \mathrm{P}_{3} \mathrm{O}_{9} \cdot \mathrm{H}_{2} \mathrm{O}^{34,35}$. In what follows, the transition of a hydrate is considered in which neither the hydrate nor the anion is destroyed.

\section{Transitions of sodium tetrametaphosphate tetrahydrate}

Examples of the influence of external factors upon the transitions of phosphates are found in the transitions of sodium tetrametaphosphate tetrahydrate and sodium triphosphate hexahydrate. The tetrametaphosphate will be discussed first. In this transition $\mathrm{Na}_{4} \mathrm{P}_{4} \mathrm{O}_{12} \cdot 4 \mathrm{H}_{2} \mathrm{O}$ suffers a crystallographic change at $54^{\circ} \mathrm{C}$ without destroying the hydrate. Conflicting data have been reported concerning the nature of this transition, and the following work was done to clarify these diverse viewpoints.

The two crystal forms of sodium tetrametaphosphate tetrahydrate have been referred to as the $\alpha$ and $\beta$ forms, T and M forms and I and II forms, as well as the boat and chair forms. Following the conventions normally used in phosphate chemistry the higher temperature form will be named Form I and the lower temperature form will be referred to as Form II in this work. (Unfortunately, the conventions for naming phases in an orderly manner have been almost universally ignored, and today no system is followed.)

Earlier work on the hydrates of sodium tetrametaphosphate ${ }^{36}$ reports a decahydrate which suffers a transition to Form II sodium tetrametaphosphate tetrahydrate at $40^{\circ} \mathrm{C}$. It was also reported that the Form II tetrametaphosphate was transformed into Form I tetrametaphosphate at $54^{\circ} \mathrm{C}$, but that the transition is irreversible. Later workers were incapable of inducing a transition of either form of the sodium tetrametaphosphate tetrahydrate into the other form at $54^{\circ} \mathrm{C}^{37}$.

Sodium tetrametaphosphate tetrahydrate was prepared from $\mathrm{Na}_{2} \mathrm{H}_{2} \mathrm{P}_{4} \mathrm{O}_{12}$ as recommended by the author ${ }^{38}$. The product obtained is Form II $\mathrm{Na}_{4} \mathrm{P}_{4} \mathrm{O}_{12} \cdot 4 \mathrm{H}_{2} \mathrm{O}$ containing no Form I Na $4 \mathrm{P}_{4} \mathrm{O}_{12} \cdot 4 \mathrm{H}_{2} \mathrm{O}$ as determined by $x$-ray diffraction. To ensure the precipitation of Form II Na $\mathrm{Na}_{4} \mathrm{O}_{12} \cdot 4 \mathrm{H}_{2} \mathrm{O}$ the phosphate is precipitated at a temperature below $20^{\circ}$.

Air-dried crystals of Form II Na $\mathrm{P}_{4} \mathrm{O}_{12} \cdot 4 \mathrm{H}_{2} \mathrm{O}$ were heated in sealed containers at $90^{\circ} \mathrm{C}$ for several hours without any detectable conversion by $\mathrm{x}$-ray diffraction of Form II to Form I. On the other hand samples of air-dried Form I Na $\mathrm{P}_{4} \mathrm{O}_{12} \cdot 4 \mathrm{H}_{2} \mathrm{O}$ were cooled to dry-ice temperature for several hours without any detectable conversion of Form I into Form II.

Sodium tetrametaphosphate decahydrate contains over 30 per cent water and perhaps the excess water was responsible for the transition of Form II 
$\mathrm{Na}_{4} \mathrm{P}_{4} \mathrm{O}_{12} \cdot 4 \mathrm{H}_{2} \mathrm{O}$ to Form I as observed by the earlier workers. It was learned that if distilled water is added to $\mathrm{Na}_{4} \mathrm{P}_{4} \mathrm{O}_{12} \cdot 4 \mathrm{H}_{2} \mathrm{O}$ to raise the total water content of the system to about 20 per cent, the $54^{\circ} \mathrm{C}$ transition from Form II to Form I becomes quantitative.

Two-gram samples of Form II $\mathrm{Na}_{4} \mathrm{P}_{4} \mathrm{O}_{12} \cdot 4 \mathrm{H}_{2} \mathrm{O}$ containing 13 per cent added water were sealed in glass vials containing thermocouple wells. The vials were placed in a differential thermal analysis instrument containing $\mathrm{MgO}$ as a reference sample. The sample was heated to $80^{\circ} \mathrm{C}$ at a heating rate of $1.5^{\circ} \mathrm{C} / \mathrm{min}$. The only thermal activity noted was a slight baseline shift in the exothermic direction which started at $52^{\circ} \mathrm{C}$ and continued to $80^{\circ} \mathrm{C}$ where the furnace was cut off. There was also no thermal activity in the cooling curve, but when the sample had cooled to room temperature the vial was opened and the sample was again subjected to $x$-ray analysis. It was found that the sample had converted to Form I during the heating. The exothermic baseline shift at $52^{\circ} \mathrm{C}$ in the thermal analysis probably indicates that the sample was partly amorphous. Thermodynamics demand that the transition of a crystal from a low temperature form to a higher temperature form be endothermic as the temperature is raised ${ }^{29}$.

All attempts to convert the solid Form I Na $\mathrm{P}_{4} \mathrm{O}_{12} \cdot 4 \mathrm{H}_{2} \mathrm{O}$ back to Form II by way of a transition failed to yield Form II Na $\mathrm{P}_{4} \mathrm{O}_{12} \cdot 4 \mathrm{H}_{2} \mathrm{O}$. Pure Form II $\mathrm{Na}_{4} \mathrm{P}_{4} \mathrm{O}_{12} \cdot 4 \mathrm{H}_{2} \mathrm{O}$ can easily be prepared from $\mathrm{Na}_{2} \mathrm{H}_{2} \mathrm{P}_{4} \mathrm{O}_{12}$ and Form I can easily be prepared from the Form II $\mathrm{Na}_{4} \mathrm{P}_{4} \mathrm{O}_{12} \cdot 4 \mathrm{H}_{2} \mathrm{O}$ by heating a damp sample of Form II to $70^{\circ} \mathrm{C}$ for one hour.

It is concluded that the observations of both previous studies were correct. In the transition from the decahydrate to the tetrahydrate at $40^{\circ} \mathrm{C}$, the phosphate retains sufficient residual water at $54^{\circ} \mathrm{C}$ to initiate the transition of Form II sodium tetrametaphosphate tetrahydrate into Form I tetrametaphosphate tetrahydrate. The transition is indeed irreversible. On the other hand, dry sodium tetrametaphosphate tetrahydrate suffers no transition at $54^{\circ} \mathrm{C}$ and atmospheric pressure.

\section{.The dehydration of $\mathrm{Na}_{5} \mathrm{P}_{3} \mathrm{O}_{10} \cdot 6 \mathrm{H}_{2} \mathrm{O}$}

The dehydration of sodium triphosphate hexahydrate has been the subject of several detailed and enlightening articles published during the last fifty years. Although much knowledge has been gained of the behaviour of the phosphate during the dehydration of the hexahydrate, the chemistry is complex and very elusive. The very fact that a reaction occurs at all between a salt and its water of crystallization during the dehydration of the salt is not easily predicted. Huber ${ }^{33}$ did much to establish sodium triphosphate as a true chemical compound. He also gave evidence that sodium triphosphate hexahydrate degraded to a mixture of ortho- and pyrophosphates when the salt was dehydrated. This aspect of the chemistry of sodium triphosphate was not long in receiving the attention of Bonneman-Bemia.

In 1941 Bonneman-Bemia ${ }^{39}$ reported that the $\mathrm{Na}_{5} \mathrm{P}_{3} \mathrm{O}_{10} \cdot 6 \mathrm{H}_{2} \mathrm{O}$ crystals decomposed to a mixture of tetrasodium pyrophosphate and sodium dimetaphosphate when the $\mathrm{Na}_{5} \mathrm{P}_{3} \mathrm{O}_{10}{ }^{\circ} 6 \mathrm{H}_{2} \mathrm{O}$ was heated. Raistrick ${ }^{40}$ in 1949 and Thilo and Seeman ${ }^{41}$ in 1951 showed that the products of the reaction were pyrophosphate and orthophosphate. To date, no one has succeeded in proving the existence of dimetaphosphate. In 1952 Thilo $^{42}$ again attacked the 
problem and concluded that the products of the triphosphate degradation were pyro- and orthophosphates in a one to one mole ratio. This is the same conclusion Raistrick had reached in 1949. Thilo showed that the molecular weights from which Bonneman-Bemia concluded that dimetaphosphate was a product resulted purely by chance and resulted because Bonneman-Bemia had failed to consider the retained water in the phosphate as well as that which had been vaporized.

In 1954 Quimby ${ }^{43}$ demonstrated that the contention of most of the previous authors was correct. Pyro and ortho are the only products of the dehydration degradation of $\mathrm{Na}_{5} \mathrm{P}_{3} \mathrm{O}_{10} \cdot 6 \mathrm{H}_{2} \mathrm{O}$. But Quimby recognized that the ratio of pyro- to orthophosphate was not a simple one to one mole ratio as is obtained when triphosphate is hydrolysed in dilute aqueous solutions. As shown in Table 1, the ratio of pyro- to orthophosphate can vary over wide limits, depending upon conditions.

In 1957 Griffith $^{44}$ showed by means of a thermobalance that five of the six water molecules were easily lost from the hexahydrate and that the water loss could be used as a means of analysis under controlled conditions. No attempt was made to determine the products of the reaction. In 1957 Zettlemoyer, Schneider, Anderson and Fuchs ${ }^{45}$ showed that $\mathrm{Na}_{5} \mathrm{P}_{3} \mathrm{P}_{10} \cdot 6 \mathrm{H}_{2} \mathrm{O}$ could be dehydrated to $\mathrm{Na}_{5} \mathrm{P}_{3} \mathrm{O}_{10}$ II without decomposing the phosphate, provided the water was removed as an azeotrope of an organic liquid such as $n$-butyl alcohol or xylene. They also showed that the rate of water loss from the hexahydrate could be plotted as a first order reaction with respect to $\mathrm{Na}_{5} \mathrm{P}_{3}$ $\mathrm{O}_{10} \cdot 6 \mathrm{H}_{2} \mathrm{O}$. Most significant is the fact that the data indicate a change of mechanism between $105^{\circ} \mathrm{C}$ and $110^{\circ} \mathrm{C}$ and that the rate of loss of water is greater at $105^{\circ} \mathrm{C}$ than it is between $110^{\circ} \mathrm{C}$ and $120^{\circ} \mathrm{C}$.

Shen, Metcalf and $\mathrm{O}^{\prime} \mathrm{Grady}^{46}$ measured the rate of water loss from the hexahydrate at temperatures of $70^{\circ} \mathrm{C}$ and below. They concluded that the rate of dehydration depended upon the surface area of the crystals and that the rate was initially rather rapid and then slowed down when one or two molecules of water were lost from the hexahydrate.

In 1960 Groves and Edwards ${ }^{47}$ reported some very interesting results from their work on the dehydration of $\mathrm{Na}_{5} \mathrm{P}_{3} \mathrm{O}_{10} \cdot 6 \mathrm{H}_{2} \mathrm{O}$. They showed that a high vapour pressure of water over the hexahydrate influenced its rate of dehydration. They also found that if the water vapour pressures were great enough (over $147 \mathrm{~mm}$ at $100^{\circ} \mathrm{C}$ ) $\mathrm{Na}_{5} \mathrm{P}_{3} \mathrm{O}_{10} \cdot 6 \mathrm{H}_{2} \mathrm{O}$ could be dehydrated directly to $\mathrm{Na}_{5} \mathrm{P}_{3} \mathrm{O}_{10}$ II without decomposing the phosphate. The authors did not attempt to explain exactly what the water vapour does, but they did point out that water vapour is known to aid in the crystallization of amorphous phosphates.

More recently, the Russian literature is rich in studies of the degradation of sodium triphosphate hydrates. Prodan, Pavlyuchenko, Lesnikvovich, Zonov, Sotnikova-Yuzhik, and Kunitskaya have contributed extensive, detailed studies of the degradation of $\mathrm{Na}_{5} \mathrm{P}_{3} \mathrm{O}_{10} \cdot 6 \mathrm{H}_{2} \mathrm{O}^{58-74}$.

The claimed products of the dehydration of $\mathrm{Na}_{5} \mathrm{P}_{3} \mathrm{O}_{10} \cdot 6 \mathrm{H}_{2} \mathrm{O}$ range anywhere from the dimetaphosphate and tetrasodium pyrophosphate, to equimolar mixtures of ortho- and pyrophosphates to mixtures of $\mathrm{Na}_{5} \mathrm{P}_{3} \mathrm{O}_{10}$ (II), $\mathrm{Na}_{4} \mathrm{P}_{2} \mathrm{O}_{7}, \mathrm{Na}_{3} \mathrm{H}_{3}\left(\mathrm{PO}_{4}\right)_{2}$ or $\mathrm{NaH}_{3} \mathrm{P}_{2} \mathrm{O}_{7} \cdot \mathrm{H}_{2} \mathrm{O}$ to pure $\mathrm{Na}_{5} \mathrm{P}_{3} \mathrm{O}_{10}$ (II). This can only mean that the reaction appears to be very simple, but is in fact 
complex. The behaviour of the sodium triphosphate hexahydrate during dehydration is remarkably dependent upon the conditions of the dehydration.

The rates of dehydration of the sodium triphosphate hexahydrate are as dependent upon the conditions of dehydration as are the products. It has been established that temperature, water vapour pressure, surface area of the crystals, bed depth of phosphate and flow of the atmosphere over the phosphate are surely variables. Other factors which are probably involved are crystal habit, crystal quality, and surface impurities on the crystal. When all of these factors are considered simultaneously, it is remarkable that the literature on the dehydration of sodium triphosphate hexahydrate is not considerably more confusing than it is. The quality of the research speaks well of the investigators and the care which has been exercised. None of the early workers could have possibly anticipated the status of the system today.

When urea is added to the sodium triphosphate an additional variable has been intentionally added to an already complicated and only partially understood system. Crystal behaviour suggests that the dehydration of a sodium triphosphate hexahydrate should begin on the surface of the crystal at some point of strain. The hydrolysis of the initial molecule of triphosphate produces mobile hydrogen ions. For example:

$$
\begin{gathered}
\mathrm{Na}_{5} \mathrm{P}_{3} \mathrm{O}_{10} \cdot 6 \mathrm{H}_{2} \mathrm{O} \rightarrow \mathrm{Na}_{4} \mathrm{P}_{2} \mathrm{O}_{7}+\mathrm{NaH}_{2} \mathrm{PO}_{4}+5 \mathrm{H}_{2} \mathrm{O} \\
2 \mathrm{Na}_{5} \mathrm{P}_{3} \mathrm{O}_{10} \cdot 6 \mathrm{H}_{2} \mathrm{O} \rightarrow \mathrm{Na}_{4} \mathrm{P}_{2} \mathrm{O}_{7}+2 \mathrm{Na}_{3} \mathrm{HP}_{2} \mathrm{O}_{7}+11 \mathrm{H}_{2} \mathrm{O}
\end{gathered}
$$

It is well known that hydrogen ions catalyse the hydrolysis of condensed phosphates in solution and there is every reason to believe that the same is true in an amorphous phase. Once the reaction has commenced it is selfpropagating. Each degradation produces new hydrogen ions and these new ions are contained in an amorphous phase which is thermodynamically unstable and mobile when compared to the crystalline phase.

It was reasoned that if the initial surface hydrolysis could be prevented in some manner, the water could be removed from a crystal of $\mathrm{Na}_{5} \mathrm{P}_{3} \mathrm{O}_{10} \cdot 6 \mathrm{H}_{2} \mathrm{O}$ without degrading the phosphate even though the phosphate was dehydrated under conditions which normally destroy the triphosphate anion.

Sears ${ }^{48}$. had demonstrated that urea was capable of removing the water of composition from orthophosphoric acid at relatively low temperatures to form ammonium phosphates.

$$
\begin{aligned}
& (n+2) \mathrm{H}_{3} \mathrm{PO}_{4}+(n+1)\left(\mathrm{NH}_{2}\right)_{2} \mathrm{CO} \rightarrow \underset{\mathrm{OOP}}{\mathrm{O}}\left[\begin{array}{c}
\mathrm{O} \\
\mathrm{NH}_{4}
\end{array}\left[\begin{array}{c}
\mathrm{OP} \\
\mathrm{O} \\
\mathrm{NH}_{4}
\end{array}\right]_{n}^{\mathrm{O}} \underset{\mathrm{NH}}{\mathrm{O}}\right. \\
& +n \mathrm{NH}_{3}+(n+1) \mathrm{CO}_{2}
\end{aligned}
$$

Here the urea acts as a dehydrating agent which leaves no residue either metallic or acidic. It will be shown that the urea is capable of causing the condensation of alkali metal phosphates at low temperatures $\left(150^{\circ} \mathrm{C}\right)$. If the urea is capable of causing condensation of phosphates, it should be capable of preventing the reverse reaction; that is, hydrolysis, if the crystals of $\mathrm{Na}_{5} \mathrm{P}_{3} \mathrm{O}_{10}{ }^{\circ}$ $6 \mathrm{H}_{2} \mathrm{O}$ were coated with urea. 
The series of events which happen are as follows. A molecule of $\mathrm{Na}_{5} \mathrm{P}_{3} \mathrm{O}_{10}$ on the surface is attacked by $\mathrm{H}_{2} \mathrm{O}$.

$$
\mathrm{Na}_{5} \mathrm{P}_{3} \mathrm{O}_{10}+\mathrm{H}_{2} \mathrm{O} \rightarrow \mathrm{Na}_{2} \mathrm{HPO}_{4}+\mathrm{Na}_{3} \mathrm{HP}_{2} \mathrm{O}_{7}
$$

then since the urea is on the surface of the crystal and the reaction starts at the surface, the urea repairs the damage.

$$
\mathrm{Na}_{2} \mathrm{HPO}_{4}+\mathrm{Na}_{3} \mathrm{HP}_{2} \mathrm{O}_{7}+\left(\mathrm{NH}_{2}\right)_{2} \mathrm{CO} \rightarrow \mathrm{Na}_{5} \mathrm{P}_{3} \mathrm{O}_{10}+2 \mathrm{NH}_{3}+\mathrm{CO}_{2}
$$

There is some recombination of two molecules of $\mathrm{Na}_{3} \mathrm{HP}_{2} \mathrm{O}_{7}$ also,

$$
2 \mathrm{NaHP}_{2} \mathrm{O}_{7}+\left(\mathrm{NH}_{2}\right)_{2} \mathrm{CO} \rightarrow \mathrm{Na}_{6} \mathrm{P}_{4} \mathrm{O}_{13}+2 \mathrm{NH}_{3}+\mathrm{CO}_{2}
$$

because there is always some tetraphosphate found in the chromatograms of the systems protected by urea.

One additional point which must be considered is the fact that an amorphous sodium polyphosphate has an infinite solubility in water. This causes amorphous phosphates to be hygroscopic and no truly equilibrium concentration of water can be adsorbed by the amorphous phosphate. The urea in the system aids to prevent the build-up of amorphous solids and in turn reduces the tendency for the phosphate to hold and react with the water. If the relative humidity of the air surrounding the phosphate during the dehydration of the $\mathrm{Na}_{5} \mathrm{P}_{3} \mathrm{O}_{10} \cdot 6 \mathrm{H}_{2} \mathrm{O}$ is great enough, the urea will lose part of its effectiveness in some temperature ranges. It was found that urea was not very effective when the phosphate was dehydrated in an open forced air oven at $110^{\circ} \mathrm{C}$ if the relative humidity in the room was 80 per cent greater.

To control the atmosphere over the phosphates during dehydration, a small furnace was constructed which contained two chambers, each of which was about $0.25 \mathrm{ft}^{3}$ in volume. The two chambers were connected in series. The first chamber was employed to preheat the air which was metered into the furnace before it was passed into the dehydrating chamber. The furnace temperature was controlled to $\pm 0.5^{\circ} \mathrm{C}$. The air which entered the furnace was pumped through a saturated salt solution and a vapour trap before it was passed into the preheater chamber.

Four water vapour pressures were chosen. A vapour pressure of $7.4 \mathrm{~mm}$ was obtained by passing air through a saturated solution of $\mathrm{CaCl}_{2} \cdot 6 \mathrm{H}_{2} \mathrm{O}$. While a vapour pressure of $10.0 \mathrm{~mm}$ was obtained with saturated $\mathrm{K}_{2} \mathrm{CO}_{3} \cdot 2 \mathrm{H}_{2} \mathrm{O}$, the vapour pressure of $12.4 \mathrm{~mm}$ was obtained with saturated $\mathrm{Mg}\left(\mathrm{NO}_{3}\right)_{2} \cdot 6 \mathrm{H}_{2} \mathrm{O}$ and a vapour pressure of $19.2 \mathrm{~mm}$ was obtained with saturated $\left(\mathrm{NH}_{4}\right)_{2} \mathrm{SO}_{4}$.

Table 1 shows the influence of urea on the degradation products of $\mathrm{Na}_{5} \mathrm{P}_{3} \mathrm{O}_{10} \cdot 6 \mathrm{H}_{2} \mathrm{O}$ as a function of urea concentration, temperature and relative humidity of the air at $25^{\circ} \mathrm{C}$ which was pumped into the furnace at $2 \mathrm{ft}^{3} / \mathrm{h}$. The samples were prepared by dissolving the required quantity of urea in $50 \mathrm{ml}$ of water and then pouring the urea solution over $95 \mathrm{~g}$ of $\mathrm{Na}_{5} \mathrm{P}_{3} \mathrm{O}_{10} \cdot 6 \mathrm{H}_{2} \mathrm{O}$ crystal which had been passed through 250 mesh screen. The slurry was put in a 6 in. Petri dish and allowed to dry for twelve hours. Then the cake of urea-coated phosphate was broken up and air dried for six hours.

The samples of phosphates used in the dehydration were prepared by cover- 
Table 1. The influence of the concentration of urea temperature of dehydration and water vapour (V.P.) pressure on the products of a $15 \mathrm{~h}$ dehydration of $\mathrm{Na}_{5} \mathrm{P}_{3} \mathrm{O}_{10} \cdot 6 \mathrm{H}_{2} \mathrm{O}$

\begin{tabular}{|c|c|c|c|c|c|}
\hline \multirow[b]{2}{*}{$\%$ Urea } & \multirow[b]{2}{*}{ Trimeta } & \multicolumn{3}{|c|}{ Percentage of total phosphorus as } & \multirow[b]{2}{*}{$\frac{\Delta \text { moles Pyro }}{\Delta \text { moles Ortho }}$} \\
\hline & & Tri & Pyro & Ortho & \\
\hline \multirow{2}{*}{$\begin{array}{l}\text { (Starting) } \\
\text { (material) }\end{array}$} & 0.69 & 97.52 & 1.72 & 0.07 & \\
\hline & \multicolumn{5}{|c|}{ V.P. $\mathrm{H}_{2} \mathrm{O}=7.4 \mathrm{~mm}$} \\
\hline 1 & 0.12 & 54.78 & 36.59 & 8.51 & 2.05 \\
\hline 2 & 0.23 & 81.08 & 14.78 & 3.91 & 1.67 \\
\hline 3 & 0.59 & 86.52 & 10.33 & 2.56 & 1.68 \\
\hline \multirow[t]{2}{*}{5} & 0.24 & 87.14 & 10.00 & 2.62 & 1.58 \\
\hline & \multicolumn{4}{|c|}{ V.P. $\mathrm{H}_{2} \mathrm{O}=7.4 \mathrm{~mm}$} & \\
\hline 0 & 0.23 & 11.93 & 78.58 & 9.26 & 4.15 \\
\hline 1 & 0.32 & 81.38 & 15.53 & 2.77 & 2.49 \\
\hline 2 & 0.32 & 86.80 & 9.99 & 2.89 & 1.43 \\
\hline 3 & 0.46 & 73.42 & 22.94 & 3.18 & 3.34 \\
\hline \multirow[t]{2}{*}{5} & 0.14 & 89.50 & 6.96 & 3.40 & 0.77 \\
\hline & \multicolumn{4}{|c|}{ V.P. $\mathrm{H}_{2} \mathrm{O}=7.4 \mathrm{~mm}$} & \\
\hline 0 & 0.27 & 67.18 & 30.66 & 1.89 & 7.66 \\
\hline 1 & 0.25 & 92.48 & 5.05 & 2.22 & 0.75 \\
\hline 2 & 0.24 & 92.52 & 4.76 & 2.47 & 0.62 \\
\hline 3 & 0.29 & 88.77 & 7.92 & 3.02 & 1.03 \\
\hline \multirow[t]{2}{*}{5} & \multirow{2}{*}{\multicolumn{4}{|c|}{ V.P. $\mathrm{H}_{2} \mathrm{O}=10.0 \mathrm{~mm}$}} & 0.37 \\
\hline & & & & & \\
\hline 0 & 0.19 & 17.21 & 70.30 & 12.30 & 2.79 \\
\hline 1 & 0.14 & 77.39 & 17.67 & 4.80 & 1.66 \\
\hline 2 & 0.19 & 89.30 & 7.60 & 2.91 & 1.01 \\
\hline 3 & 0.31 & 89.61 & 6.98 & 3.10 & 0.85 \\
\hline \multirow[t]{2}{*}{5} & 0.18 & 92.53 & 4.76 & 2.53 & 0.60 \\
\hline & \multicolumn{4}{|c|}{ V.P. $\mathrm{H}_{2} \mathrm{O}=10.0 \mathrm{~mm}$} & \\
\hline 0 & 0.64 & 54.94 & 39.80 & 4.62 & 4.12 \\
\hline 1 & 0.34 & 91.71 & 5.61 & 2.34 & 0.83 \\
\hline 2 & 0.57 & 93.59 & 3.68 & 2.16 & 0.45 \\
\hline 3 & 0.39 & 93.07 & 4.29 & 2.25 & 0.57 \\
\hline \multirow[t]{2}{*}{5} & 0.29 & 93.59 & 3.78 & 2.34 & 0.44 \\
\hline & \multicolumn{4}{|c|}{ V.P. $\mathrm{H}_{2} \mathrm{O}=12.4 \mathrm{~mm}$} & \\
\hline 0 & 0.14 & 6.27 & 69.85 & 23.74 & 1.43 \\
\hline 1 & 0.11 & 70.36 & 21.41 & 8.12 & 1.21 \\
\hline 2 & 0.10 & 84.37 & 11.41 & 4.12 & 1.18 \\
\hline 3 & 0.07 & 91.55 & 5.58 & 2.80 & 0.69 \\
\hline \multirow[t]{2}{*}{5} & 0.04 & 92.18 & 5.37 & 2.41 & 0.76 \\
\hline & \multicolumn{4}{|c|}{ V.P. $\mathrm{H}_{2} \mathrm{O}=12.4 \mathrm{~mm}$} & \\
\hline 0 & 0.09 & 17.27 & 69.45 & 13.19 & 2.57 \\
\hline 1 & 0.29 & 90.61 & 6.76 & 2.34 & 1.08 \\
\hline 2 & 0.13 & 91.77 & 5.71 & 2.39 & 0.83 \\
\hline 3 & 0.22 & 93.51 & 4.21 & 2.06 & 0.60 \\
\hline \multirow[t]{2}{*}{5} & \multirow{2}{*}{\multicolumn{4}{|c|}{$\begin{array}{l}94.04 \\
\text { V.P. } \mathrm{H}_{2} \mathrm{O}=12.89 \\
=12.4 \mathrm{~mm}\end{array}$}} & 0.56 \\
\hline & & & & & \\
\hline 0 & 0.14 & 81.28 & 15.80 & 2.78 & 2.53 \\
\hline 1 & 0.05 & 92.10 & 5.23 & 2.62 & 0.67 \\
\hline 2 & 0.05 & 93.52 & 4.19 & 2.24 & 0.55 \\
\hline 3 & 0.19 & 94.80 & 3.31 & 1.70 & 0.47 \\
\hline 5 & 0.16 & 95.56 & 2.59 & 1.89 & 0.23 \\
\hline
\end{tabular}


ing the bottom of a 3.5 in. Petri dish with $2 \mathrm{~g}$ of the phosphate to yield a bed depth of about $1 \mathrm{~mm}$ or less. The temperature of the oven was adjusted to the required value at least twelve hours before the samples were introduced. The purge air, of adjusted humidity, was passed through the chamber for at least one hour before the samples were introduced into the oven.

The major part of the water was driven out of the samples of phosphate during the first few hours of heating, but the hydrolysis reaction can be considered irreversible under most of the conditions studied. The phosphate was, therefore, heated for 15 hours, removed from the oven, and analysed by ion exchange chromatography. It should be noted that the added urea not only increased the quantity of triphosphate remaining in the samples after dehydration, but also decreased the ratio of pyro- to ortho-, particularly at $125^{\circ} \mathrm{C}$ and $150^{\circ} \mathrm{C}$. The largest change occurred when air of $7.4 \mathrm{~mm} \mathrm{H}_{2} \mathrm{O}$ vapour pressure was pumped into the oven at $150^{\circ} \mathrm{C}$. The mole ratio of pyrophosphate to orthophosphate dropped from 7.66 when no urea was used to 0.75 when the $\mathrm{Na}_{5} \mathrm{P}_{3} \mathrm{O}_{10} \cdot 6 \mathrm{H}_{2} \mathrm{O}$ crystals were coated with one per cent urea. In many of the urea coated samples, this build-up of pyrophosphate was less than the build-up of orthophosphate. That is to say, the ratio was less than 1.0. This adds support to the concept that urea is behaving as a dehydrating agent. Either the urea is causing the pyrophosphate to recombine with ortho to reform triphosphate or some of the pyrophosphate is also degrading. The overall picture of $\mathrm{Na}_{5} \mathrm{P}_{3} \mathrm{O}_{10} \cdot 6 \mathrm{H}_{2} \mathrm{O}$ degradation does not support the latter view.

Two samples of orthophosphates with an $\mathrm{Na}_{2} \mathrm{O} / \mathrm{P}_{2} \mathrm{O}_{5}$ ratio $5 / 3$ were prepared. To one sample urea was added to satisfy the following equation.

$$
2 \mathrm{Na}_{2} \mathrm{HPO}_{4}+\mathrm{NaH}_{2} \mathrm{PO}_{4}+2\left(\mathrm{NH}_{2}\right)_{2} \mathrm{CO} \rightarrow \mathrm{Na}_{5} \mathrm{P}_{3} \mathrm{O}_{10}+4 \mathrm{NH}_{3}+\mathrm{CO}_{2}
$$

While the other sample contained no urea, both samples were placed in a $150^{\circ} \mathrm{C}$ furnace for 15 hours. The samples were then analysed for phosphate distribution.

The point of significance is the relative degrees of condensation of the samples.

A sample of sodium triphosphate hexahydrate coated with two per cent urea was heated for 15 hours at $125^{\circ} \mathrm{C}$ and $12.4 \mathrm{~mm}$ vapour pressure. The sample was treated as the previous samples had been treated except a $10 \mathrm{~g}$ sample was dehydrated. The sample was analysed for phosphate distribution as well as the quantity of ammonium nitrogen and urea nitrogen contained in the sample. The results confirm that the urea is behaving as a dehydrating agent.

Figure 1 shows two curves for the dehydration of $\mathrm{Na}_{5} \mathrm{P}_{3} \mathrm{O}_{10} \cdot 6 \mathrm{H}_{2} \mathrm{O}$ and

Table 2. The influence of urea on the condensation of orthophosphates at $150^{\circ} \mathrm{C}$

\begin{tabular}{lcc}
\hline & $\begin{array}{c}\text { Without urea } \\
\% \text { of phosphorus as }\end{array}$ & $\begin{array}{c}\text { With urea } \\
\% \text { of phosphorus as }\end{array}$ \\
\hline Ortho & 60.2 & 7.4 \\
Pyro & 39.8 & 67.2 \\
Tri & - & 14.9 \\
Longer chains & - & 10.4 \\
\hline
\end{tabular}


Table 3. The hydrolytic loss of urea from a $\mathrm{Na}_{5} \mathrm{P}_{3} \mathrm{O}_{10} \cdot 6 \mathrm{H}_{2} \mathrm{O}$ sample initially containing $2.0 \%$ urea. The sample was heated at $125^{\circ} \mathrm{C}$ for $15 \mathrm{~h}$ at $12.4 \mathrm{~mm}$ v.p.

\begin{tabular}{crcc}
\hline \multicolumn{2}{c}{ Phosphate analysis } & \multicolumn{2}{c}{ Nitrogen analysis } \\
\hline Ortho & 2.24 & \% Urea nitrogen & $-0.46 \%$ \\
Pyro & 5.01 & \% Ammonium nitrogen & $-0.00 \%$ \\
Tri & 92.63 & & \\
Trimeta & 0.13 & & \\
\hline
\end{tabular}

$\mathrm{Na}_{5} \mathrm{P}_{3} \mathrm{O}_{10} \cdot 6 \mathrm{H}_{2} \mathrm{O}$ coated with two per cent urea. These curves were obtained at $125^{\circ} \mathrm{C}$, with air of $12.4 \mathrm{~mm}$ vapour pressure being passed over the samples. The data are not precise kinetic data but adequately demonstrate that the major part of the water is driven from the samples during the first hour of heating at $125^{\circ} \mathrm{C}$.

At water loadings above 75 per cent relative humidity in the room, the urea no longer protects the phosphate from decomposing at $105^{\circ} \mathrm{C}$. If higher temperatures are employed, the urea shows protection to 81 per cent relative humidity. Two samples of phosphate containing one per cent and five per cent urea were heated at $125^{\circ} \mathrm{C}$ for $15 \mathrm{~h}$ in an air saturated to 81 per cent relative humidity at room temperature. The analysis of the phosphate showed that 75.38 per cent triphosphate remained when one per cent urea was employed and that 89.37 per cent triphosphate remained when the phosphate was coated with five per cent urea. High water vapour loadings tend to reduce the effectiveness of the urea in the inhibition of the dehydration degradation of the phosphate, but higher temperature will compensate for the loss in activity.

Thermogravimetric data indicate that the sodium triphosphate coated with urea loses the first two molecules of water more easily when the $\mathrm{Na}_{5} \mathrm{P}_{3} \mathrm{O}_{10} \cdot 6 \mathrm{H}_{2} \mathrm{O}$ crystals are coated with urea. There is a definite change of slope in the pyrolysis curve between 7 per cent and 7.5 per cent weight loss. The break in the curve occurred in both the 1 per cent and the 5 per cent urea

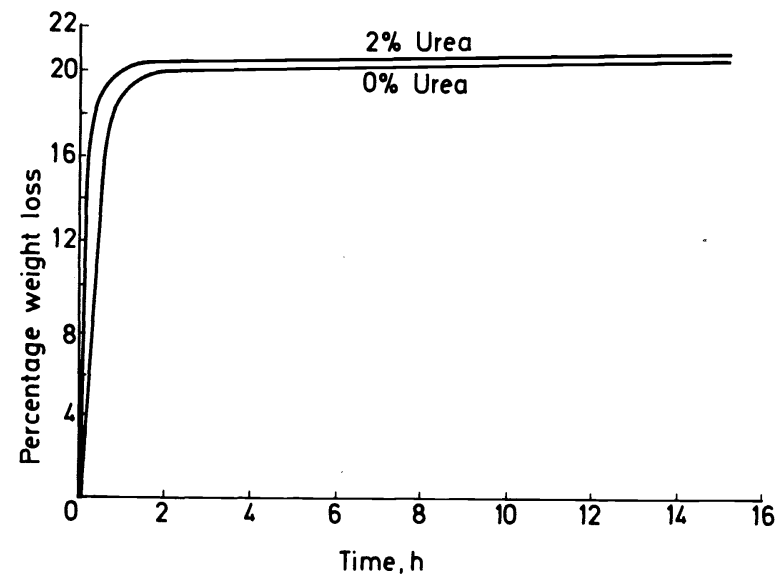

Figure 1. Weight loss of $\mathrm{Na}_{5} \mathrm{P}_{3} \mathrm{O}_{10} \cdot 6 \mathrm{H}_{2} \mathrm{O}$ at $125^{\circ} \mathrm{C}$ when air of $12.4 \mathrm{~mm}$ v.p. is passed over the phosphate. 


\section{EDWARD J. GRIFFITH}

samples, but was absent when the untreated $\mathrm{Na}_{5} \mathrm{P}_{3} \mathrm{O}_{10} \cdot 6 \mathrm{H}_{2} \mathrm{O}$ was dehydrated. The curve also shows that a major weight loss from the urea came about $132^{\circ} \mathrm{C}$, the melting point of urea.

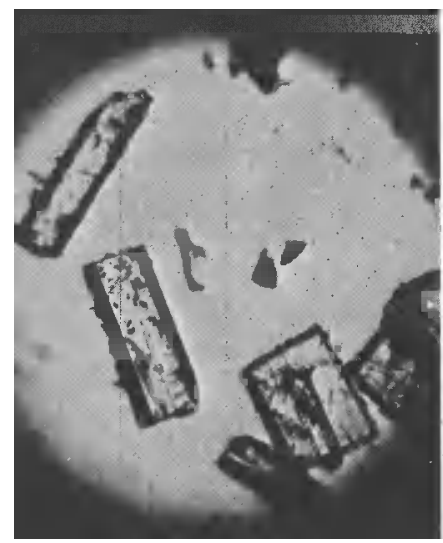

$90^{\circ} \mathrm{C}$

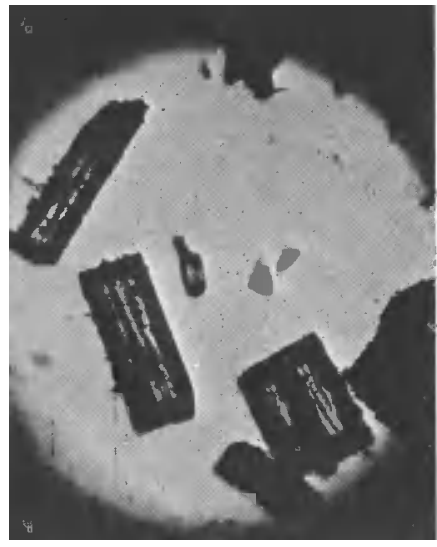

$120^{\circ} \mathrm{C}$

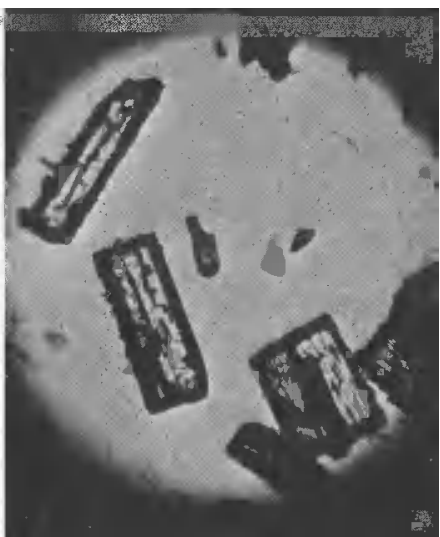

$115^{\circ} \mathrm{C}$

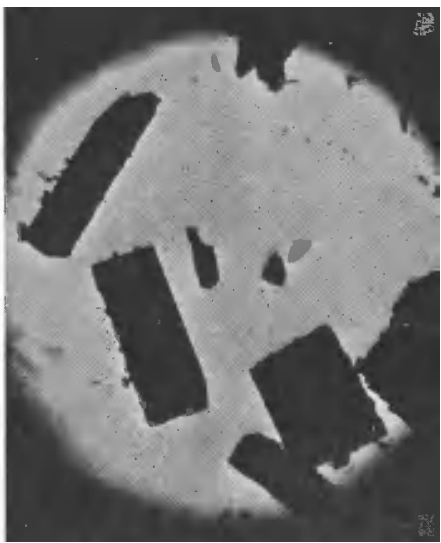

$125^{\circ} \mathrm{C}$

Figure 2. Decomposition of $\mathrm{Na}_{5} \mathrm{P}_{3} \mathrm{O}_{10} \cdot 6 \mathrm{H}_{2} \mathrm{O}$ on the hot stage microscope (heating rate $\left.\sim 2^{\circ} / \mathrm{min}\right)$.

Differential thermal analyses of the triphosphate hexahydrate show no unusual behaviour except that the urea prevents superheating of the crystals before dehydration. From a practical point of view, this could be a disadvantage because there is a tendency to lose water of hydration at a lower temperature than when the urea is absent.

Figure 2 presents a series of photographs showing the dehydration and decomposition of $\mathrm{Na}_{5} \mathrm{P}_{3} \mathrm{O}_{10} \cdot 6 \mathrm{H}_{2} \mathrm{O}$ during heating. The pictures were taken with infra-red sensitive film which improves the ability to see the inside behaviour of the crystals because the surface interference to the light is reduced. 
Several points should be noticed in the breakdown of the crystals. There is no noticeable deterioration of the crystals up to $90^{\circ} \mathrm{C}$. The picture was identical with a picture made at room temperature. When the crystals begin to deteriorate the breakdown begins at points of strain on the crystal's surface and spreads. The surface in the plane of the photograph remains almost free from attack. This is borne out when it is noticed that the transparent part of the partly decomposed crystals have the same general shape as the crystals themselves. Crystals of $\mathrm{Na}_{5} \mathrm{P}_{3} \mathrm{O}_{10} \cdot 6 \mathrm{H}_{2} \mathrm{O}$ coated with urea have the same general appearance and the dehydration to $\mathrm{Na}_{5} \mathrm{P}_{3} \mathrm{O}_{10}$ II follows the same general pattern. This is to say, the transition starts at the edges of the crystal and works its way into the crystal's interior with or without urea. Without urea the transition is from $\mathrm{Na}_{5} \mathrm{P}_{3} \mathrm{O}_{10} \cdot 6 \mathrm{H}_{2} \mathrm{O}$ to a mixture of ortho- and pyrophosphates and water vapour. With urea the transition is from $\mathrm{Na}_{5} \mathrm{P}_{3} \mathrm{O}_{10} \cdot 6 \mathrm{H}_{2} \mathrm{O}$ to $\mathrm{Na}_{5} \mathrm{P}_{3} \mathrm{O}_{10} \mathrm{II}$ and water vapour.

Table 4.

\begin{tabular}{lccc}
\hline \multicolumn{1}{c}{ Substance tested } & $\% \mathrm{P}$ as tri & \% $\mathrm{P}$ as pyro & $\% \mathrm{P}$ as ortho \\
\hline$\left(\mathrm{Na}_{5} \mathrm{P}_{3} \mathrm{O}_{10} \cdot 6 \mathrm{H}_{2} \mathrm{O}\right.$ untreated) & 17.3 & 69.5 & 13.2 \\
Urea & 91.8 & 5.7 & 2.4 \\
Guanidine & 72.9 & 15.0 & 12.1 \\
Dicyandiamine & 29.3 & 40.0 & 30.7 \\
Biuret & 17.1 & 51.0 & 31.9 \\
Ethylene urea & 47.5 & 32.7 & 19.8 \\
Biurea & 20.5 & 42.0 & 37.5 \\
Thiourea & 24.0 & 44.6 & 31.4 \\
\hline
\end{tabular}

Other systems tested are shown in Table 4. Each of the substances was added at the two per cent by weight level and was heated for 15 hours at $125^{\circ} \mathrm{C}$ with air of $12.4 \mathrm{~mm} \mathrm{H}_{2} \mathrm{O}$ vapour pressure pumped over the samples at a flowrate of $2 \mathrm{ft}^{3} / \mathrm{h}$.

Urea is the best agent found, although guanidine carbonate also functions well. Biuret probably would work well if the crystals would coat uniformly. In the attempts to use biuret, it segregated from the phosphate rather than coating the phosphate crystals.

In conclusion, it has been demonstrated that:

(1) Urea will protect sodium triphosphate hexahydrate from decomposing during dehydration;

(2) The degradation of the phosphate starts at the surface of the crystals, and if the surfaces are protected the entire crystals are protected.

(3) The urea functions as a dehydrating agent which causes the phosphates to recombine to condensed phosphates, thus removing the hydrogen ions which form during degradation.

There is need for additional new studies of the phase transitions of the condensed phosphate system, particularly at pressures greater than atmospheric. The observation that Maddrell's salt and sodium trimetaphosphate can be converted into amorphous solids simply by grinding ${ }^{49}$ suggests that the transition of Maddrell's salt into sodium trimetaphosphate may be reversible at higher pressures. 


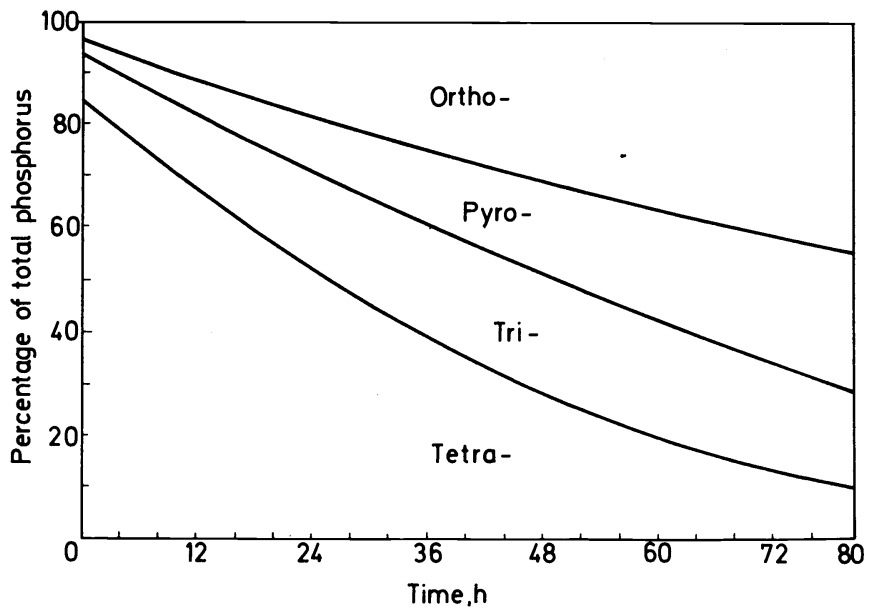

Figure 3. Cleavage family of tetraphosphate at $\mathrm{pH} 4$ and $60^{\circ} \mathrm{C}$ determined by analysis.

\section{Low temperature condensation of potassium orthophosphate}

Because urea can cause the condensation of orthophosphates at temperatures far below the normal condensation temperature employed in phase studies, a study of the condensation of mixtures of $\mathrm{KH}_{2} \mathrm{PO}_{4}$ and $\mathrm{K}_{2} \mathrm{HPO}_{4}$ was undertaken. It was desired to determine whether or not compounds could be prepared by this technique which were not normally found in equilibrium-type systems.

Potassium trimetaphosphate is not a species found in the two-component phase diagram $\mathrm{K}_{2} \mathrm{O}-\mathrm{P}_{2} \mathrm{O}_{5}$, but studies have shown that it can be prepared by the condensation of $\mathrm{KH}_{2} \mathrm{PO}_{4}$ at lower temperatures ${ }^{50,57}$. It was discovered that potassium trimetaphosphate was formed by the reaction of

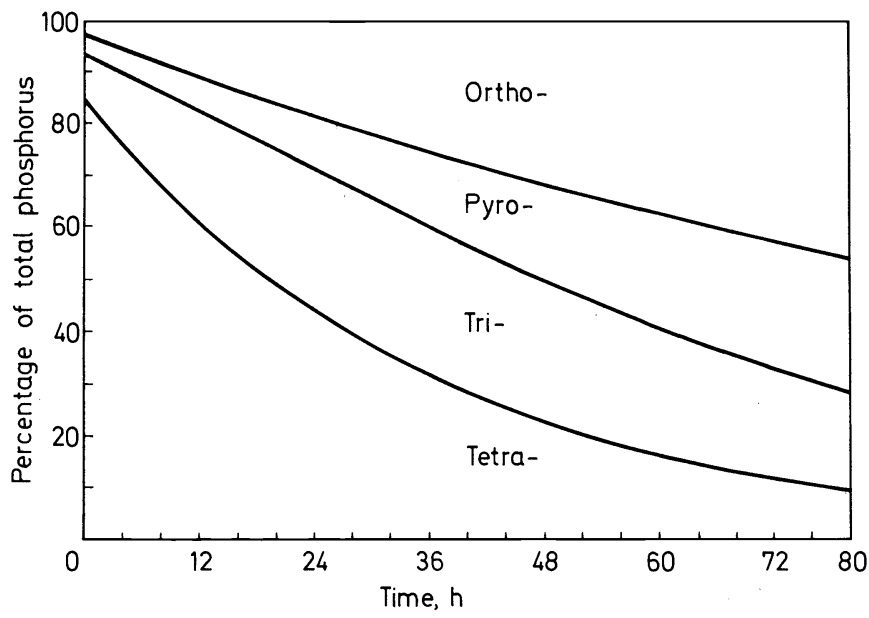

Figure 4. Cleavage family of tetraphosphate at $\mathrm{pH} 4$ and $60^{\circ} \mathrm{C}$ calculated. 


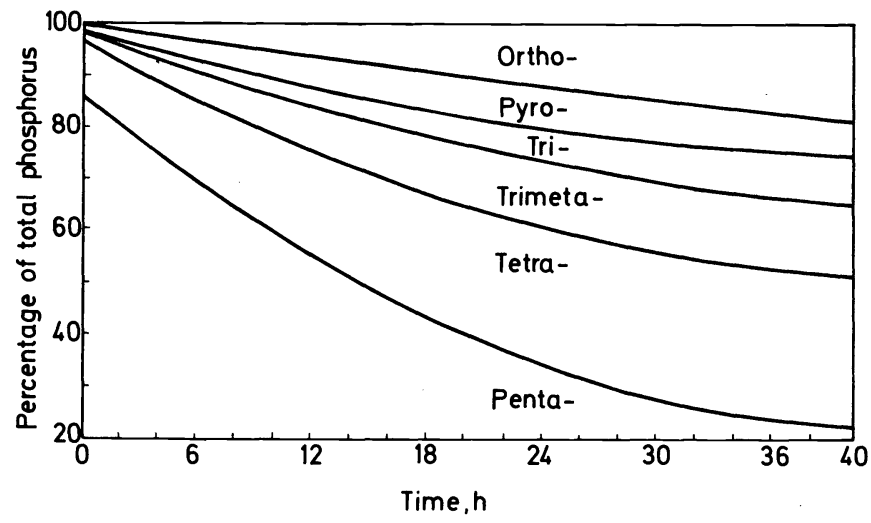

Figure 5. Cleavage family of pentaphosphate at $\mathrm{pH} 4$ and $60^{\circ} \mathrm{C}$ by analysis.

urea with $\mathrm{KH}_{2} \mathrm{PO}_{4}$. Potassium Kurrol's salt was also formed, but since the long chain phosphate was insoluble, the trimetaphosphate was easily extracted from the insoluble Kurrol's salt. Studies of the system $\mathrm{KH}_{2} \mathrm{PO}_{4}-$ $\mathrm{K}_{2} \mathrm{HPO}_{4}$-urea revealed that the maximum quantities of trimetaphosphate were formed in systems which contained a great excess of urea and were more basic than the systems which contained only $\mathrm{KH}_{2} \mathrm{PO}_{4}$ and urea.

Paper chromatography was employed as an analytical tool and the semiquantitative analyses presented were obtained by the methods recommended by Bernhart and Chess ${ }^{51}$. The results of adjusting the $\mathrm{K}_{2} \mathrm{O}-\mathrm{P}_{2} \mathrm{O}_{5}$-urea ratios, heating times, and temperatures are shown in Table 5. The maximum yield of $\mathrm{K}_{3} \mathrm{P}_{3} \mathrm{O}_{9}$ was obtained from a reaction mixture with a pentaphosphate composition and an eightfold excess of urea (Sample No. 17). The

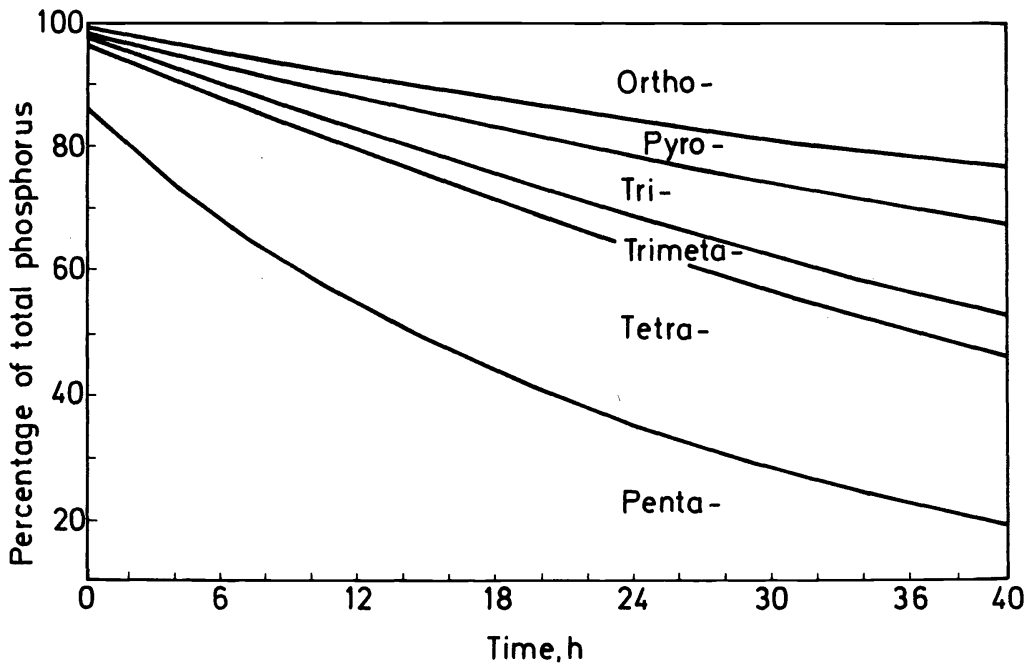

Figure 6. Cleavage family of pentaphosphate at $\mathrm{pH} 4$ and $60^{\circ} \mathrm{C}$ calculated. 
EDWARD J. GRIFFITH

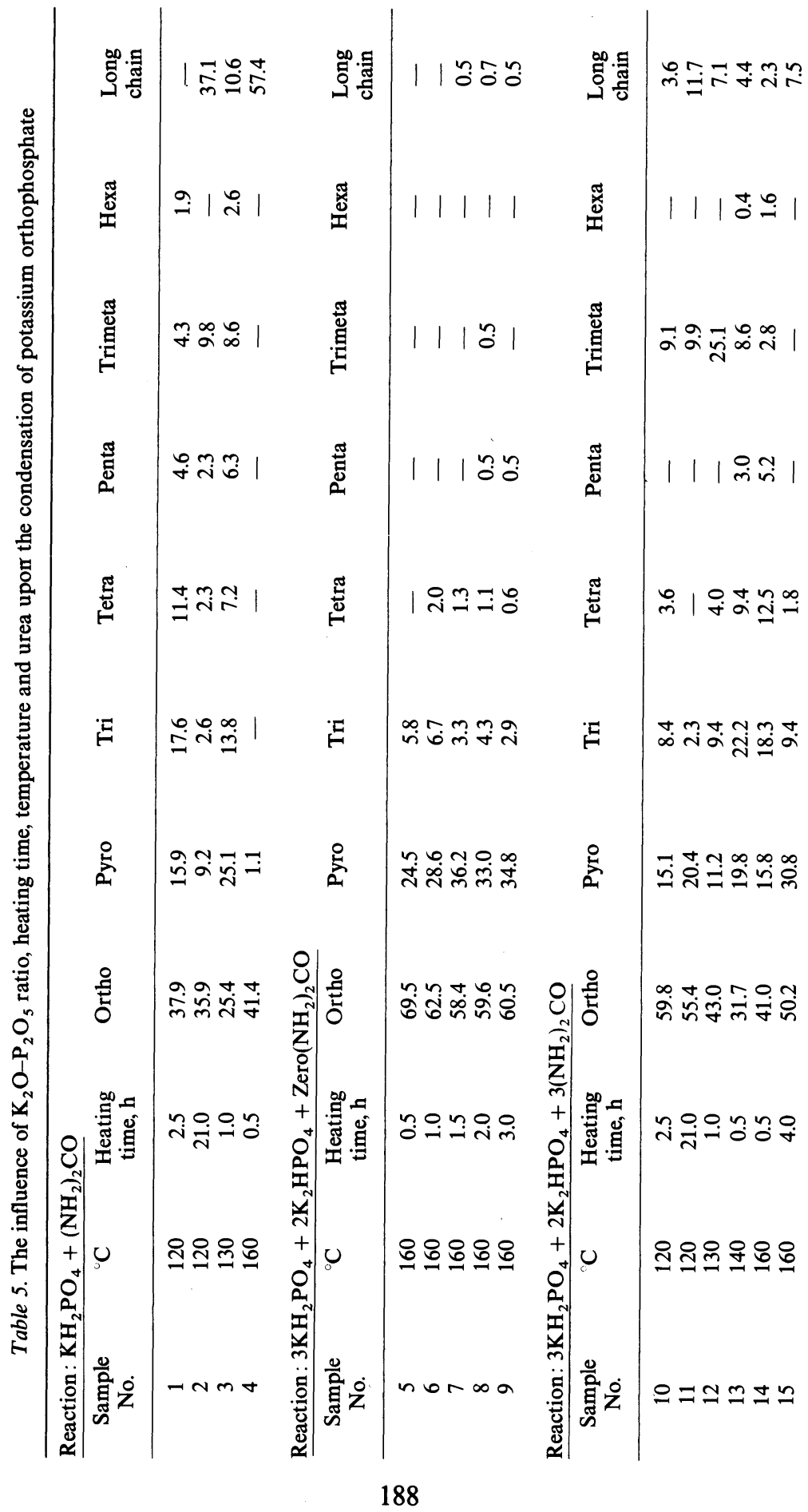


CHEMICAL AND PHYSICAL PROPERTIES OF CONDENSED PHOSPHATES

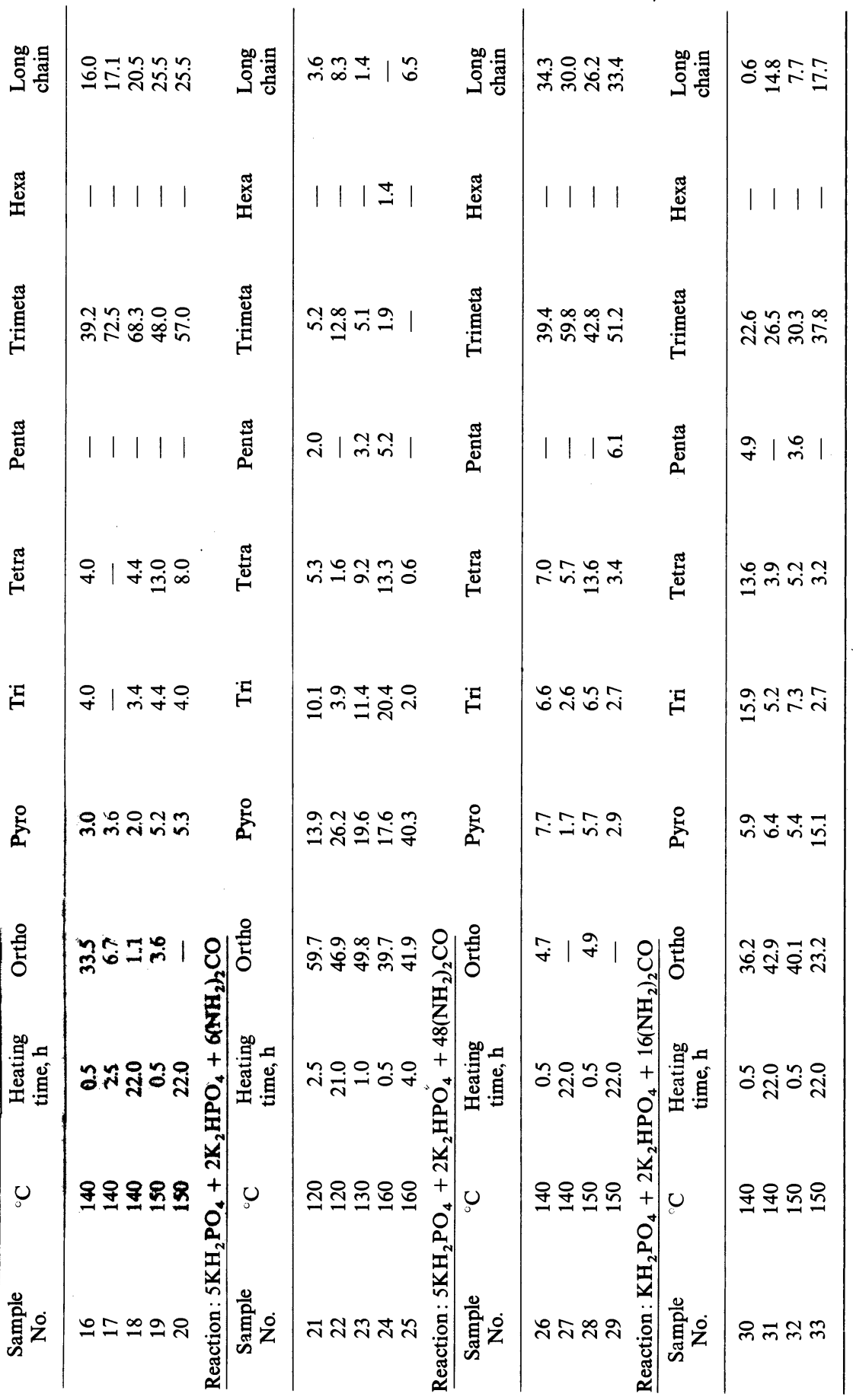




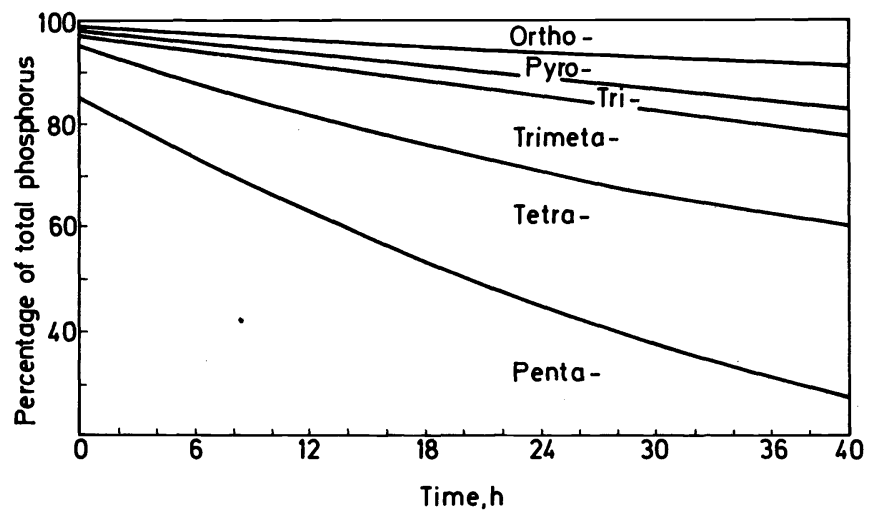

Figure 7. Cleavage family of pentaphosphate at $\mathrm{pH} 7$ and $60^{\circ} \mathrm{C}$ by analysis.

urea is probably acting as a non-aqueous solvent in the same sense Porthault employed ${ }^{57} \mathrm{NH}_{4} \mathrm{NO}_{3}$. It is interesting that no pentaphosphate was detected in the reaction products. A small decrease in the trimetaphosphate concentration was observed when the reaction mixture was heated for an additional 19.5 hours.

It should be observed that in the reactions presented in Table 8, the urea is performing a function other than solvent and dehydration. Too much trimetaphosphate and longer chain phosphate are forming for a phosphate mixture with a $\mathrm{K}_{2} \mathrm{O}-\mathrm{P}_{2} \mathrm{O}_{5}$ ratio equal to $7 / 5$. The stoichiometry would predict that no more than 60 per cent of the phosphorus could be present as rings or longer chains. Obviously the urea is reacting with $\mathrm{K}_{2} \mathrm{O}$, probably to form potassium carbonates. The solids effervesce when treated with dilute acids. The urea reaction is a reaction similar to those reported in which $\mathrm{NH}_{4} \mathrm{Cl}$ is added to pyrophosphates to remove $\mathrm{Na}_{2} \mathrm{O}$ as $\mathrm{NaCl}$, to yield $\mathrm{Na}_{3} \mathrm{P}_{3} \mathrm{O}_{9}$ as a product ${ }^{52,53}$.

The data, therefore, show that urea acts both as a dehydrating agent to cause condensation and as a metal oxide scavenger also to increase the

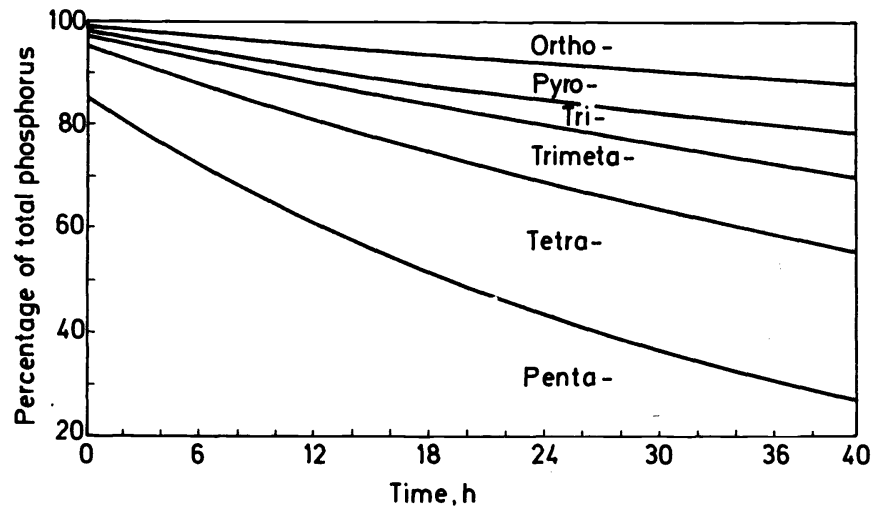

Figure 8. Cleavage family of pentaphosphate at $\mathrm{pH} 7$ and $60^{\circ} \mathrm{C}$ calculated. 


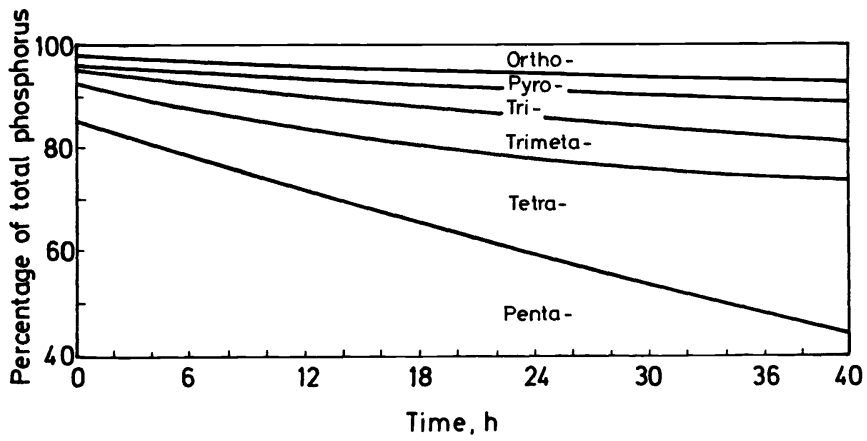

Figure 9. Cleavage family of pentaphosphate at $\mathrm{pH} 11$ and $60^{\circ} \mathrm{C}$ by analysis.

degree of condensation of the phosphate. The fact that the concentration of trimetaphosphate increases as the $\mathrm{K}_{2} \mathrm{O} / \mathrm{P}_{2} \mathrm{O}_{5}$ ratio increases to about $7 / 5$ indicates that the reaction of the urea may be represented as follows in the more basic media :

$$
\begin{gathered}
\left(\mathrm{NH}_{2}\right)_{2} \mathrm{CO}+2 \mathrm{~K}_{2} \mathrm{HPO}_{4} \rightarrow \mathrm{K}_{4} \mathrm{P}_{2} \mathrm{O}_{7}+2 \mathrm{NH}_{3}+\mathrm{CO}_{2} \rightarrow 2\left(\mathrm{KPO}_{3}\right)_{n} \\
+\mathrm{K}_{2} \mathrm{CO}_{3}+2 \mathrm{NH}_{3}
\end{gathered}
$$

The water of constitution of the phosphate first decomposes the urea to $\mathrm{NH}_{3}$ and $\mathrm{CO}_{2}$. The $\mathrm{CO}_{2}$ then reacts with the $\mathrm{K}_{2} \mathrm{O}$ of basic systems to decrease the effective $\mathrm{K}_{2} \mathrm{O}-\mathrm{P}_{2} \mathrm{O}_{5}$ ratio of the system. This probably explains the low efficiency of urea in producing $\mathrm{K}_{3} \mathrm{P}_{3} \mathrm{O}_{9}$. Most of the $\mathrm{CO}_{2}$ which is formed is lost to the atmosphere, as noted in the work with $\mathrm{Na}_{5} \mathbf{P}_{\mathbf{3}} \mathrm{P}_{10} \cdot 6 \mathrm{H}_{2} \mathrm{O}$.

The maximum condensation occurs near the melting point of urea $132^{\circ} \mathrm{C}$. There is usually a minimum of orthophosphate remaining in the temperature range between $130^{\circ}$ and $140^{\circ} \mathrm{C}$. Samples 24 and 25 are interesting examples of the crystallization of pyrophosphate. Although the orthophosphate is unchanged within experimental error, the pyrophosphate content is more than doubled. This has occurred at the expense of the longer chain phosphates. In general the condensation of the orthophosphate by the urea is rapid, but the crystallization of the phosphates may require several hours. It should also be noted that sometimes longer heating periods

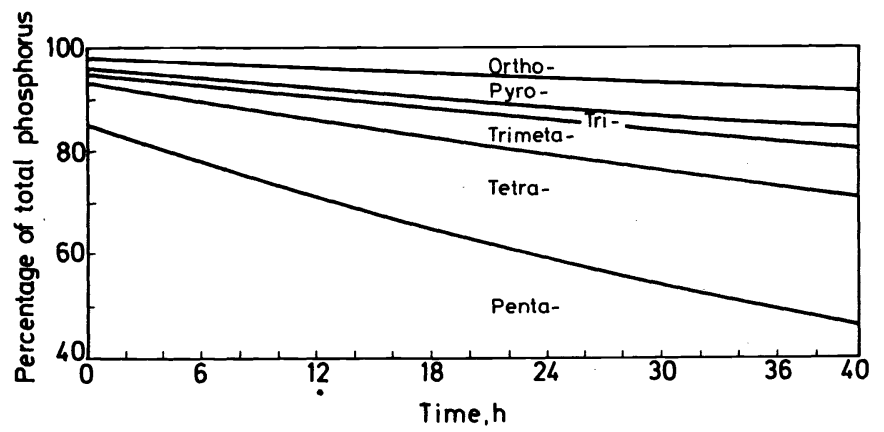

Figure 10. Cleavage family of pentaphosphate at $\mathrm{pH} 11$ and $60^{\circ} \mathrm{C}$ calculated. 


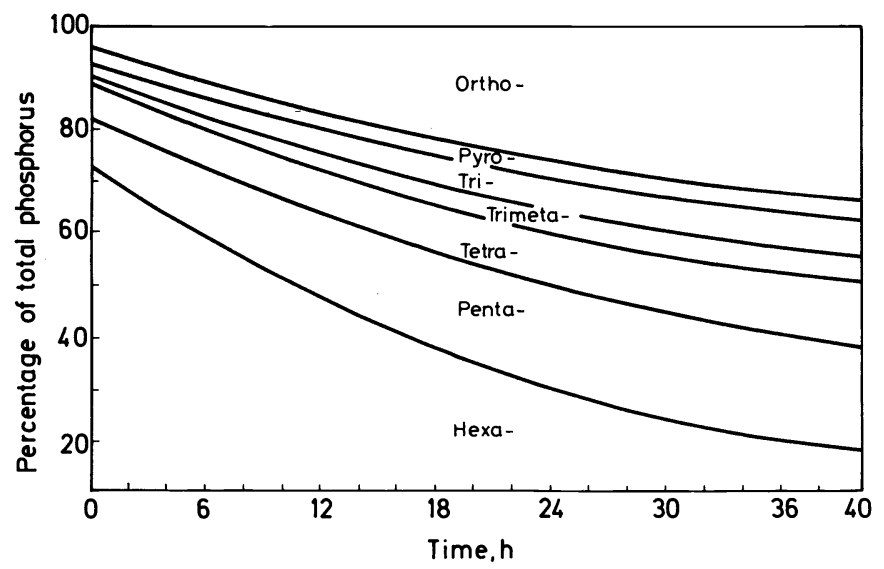

Figure 11. Cleavage family of hexaphosphate at $\mathrm{pH} 4$ and $60^{\circ} \mathrm{C}$ by analysis.

increase the orthophosphate content of the reacting mass. This suggests that orthophosphate is at times a product of the crystallization of a metastable composition to a more stable crystalline state.

\section{Hydrolytic degradation}

Of all the reactions of condensed phosphates, none has received more attention than hydrolytic degradation. Scores of articles have been written and each year several new studies are reported. Two excellent reviews of the subject have recently been published ${ }^{8,11}$. The reader is referred to these articles for background information.

In 1967 Griffith and Burton ${ }^{23}$ published rate data for the degradation of polyphosphates containing from [4] to [8] phosphorus atoms per molecule. In the published article each phosphate was treated separately and no attempt was made to treat the family of compounds which resulted from the degradation of a single intermediate chain length phosphate.

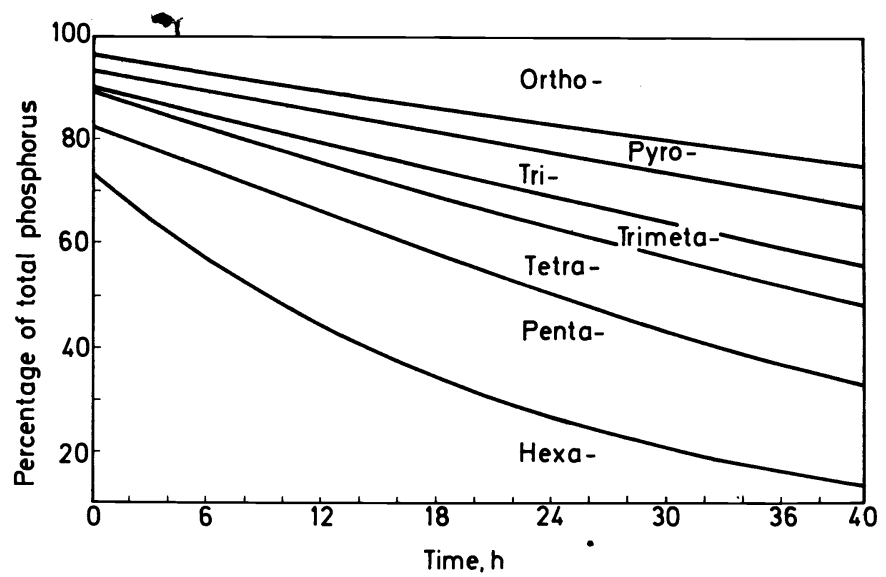

Figure 12. Cleavage family of hexaphosphate at $\mathrm{pH} 4$ and $60^{\circ} \mathrm{C}$ calculated. 


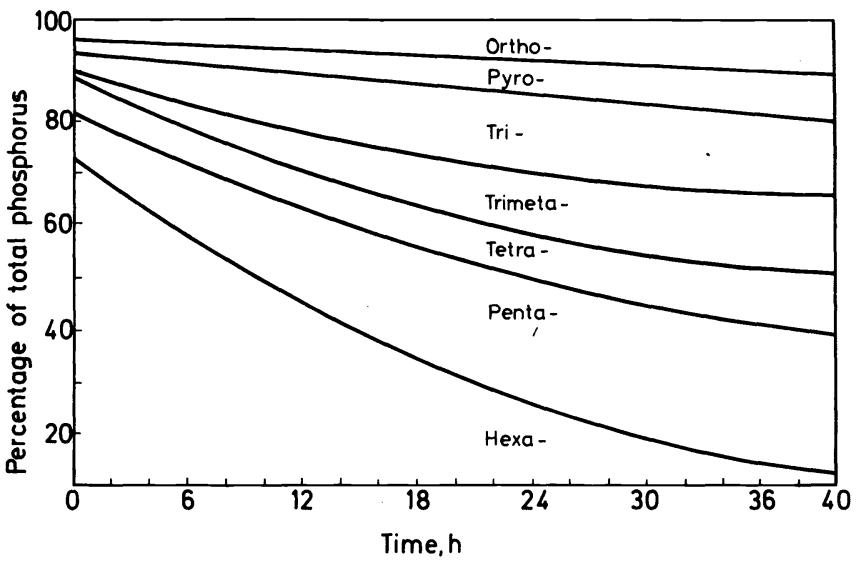

Figure 13. Cleavage family of hexaphosphate at $\mathrm{pH} 7$ and $60^{\circ} \mathrm{C}$ by analysis.

The following work presents the growth of families of condensed phosphates which result from the degradation of an intermediate chain length phosphate. Two major differences are noteworthy in the present work when compared with the previously reported rate data: (1) The highest purity phosphates available to the authors were expended upon the determination of the rate constants presented in the previous work, and (2) The analytical procedures used in the initial work were prohibitively involved to be applied in a project where entire families of compounds were to be analysed in a single sample. The work presented here is, therefore, not of the quality of the original publication, but it will be shown that the data presented in the original work can be used to calculate the results presented here about as precisely as they can be measured by the analytical techniques employed in this work.

The samples prepared for hydrolytic degradation were prepared in the

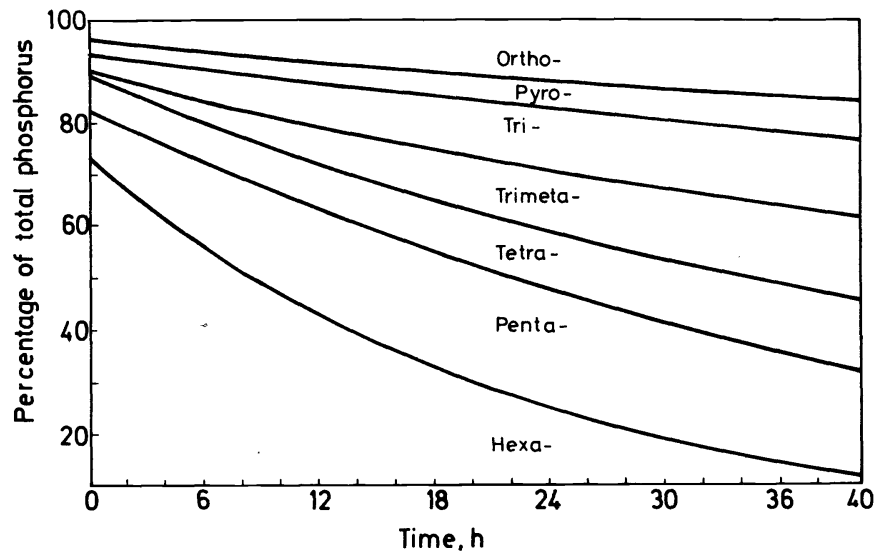

Figure 14. Cleavage family of hexaphosphate at $\mathrm{pH} 7$ and $60^{\circ} \mathrm{C}$ calculated. 


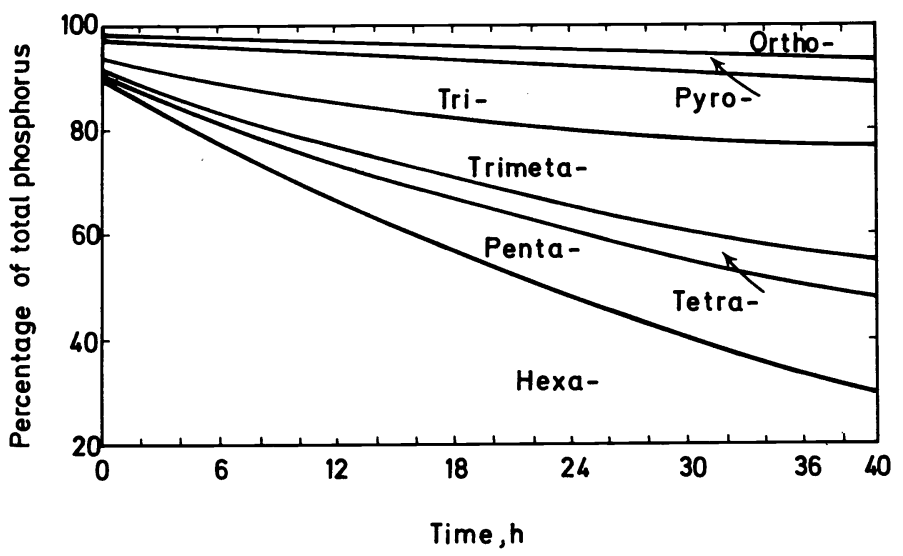

Figure 15. Cleavage family of hexaphosphate at $\mathrm{pH} 11$ and $60^{\circ} \mathrm{C}$ by analysis.

same manner as those previously reported ${ }^{23}$. The analytical techniques employed were also identical to the original work, except that the concentrations of the various phosphates in a degrading solution were measured with an Analytrol densitometer rather than by extraction techniques. The difficulties with the analyses can be appreciated when it is recognized that as many as ten individual phosphates must be simultaneously analysed from a single chromatogram.

The degradations of tetra- through octa-phosphates are presented in the odd-numbered Figures 3 through 19 as determined analytically. In the evennumbered Figures 4 through 20 the degradations have been obtained by calculating the quantities which should have been contained in the samples as predicted by the rate constants previously published.

In the work presented here, it was concluded that polyphosphates in which [n] does not exceed eight degrade by but two paths. One orthophosphate may be cleaved from the end of the chains and trimetaphosphate

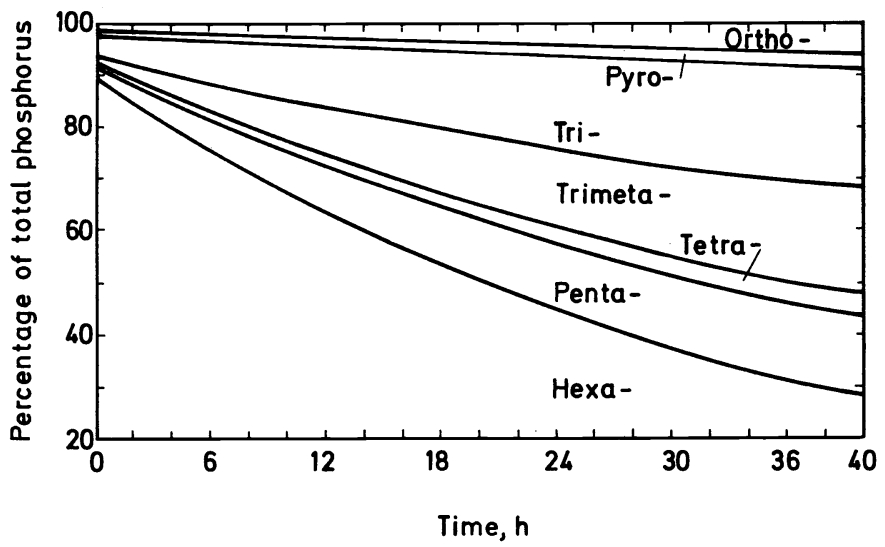

Figure 16. Cleavage family of hexaphosphate at $\mathrm{pH} 11$ and $60^{\circ} \mathrm{C}$ calculated. 
may be abstracted also from the end of the chains. If the phosphates degrade by internal scission, this type of degradation is a minor fraction of the total process under the conditions of the experiments presented here.

The following routes of degradation can be formulated for polyphosphates. The scheme can be extended indefinitely, but was terminated at octaphosphate in this work.

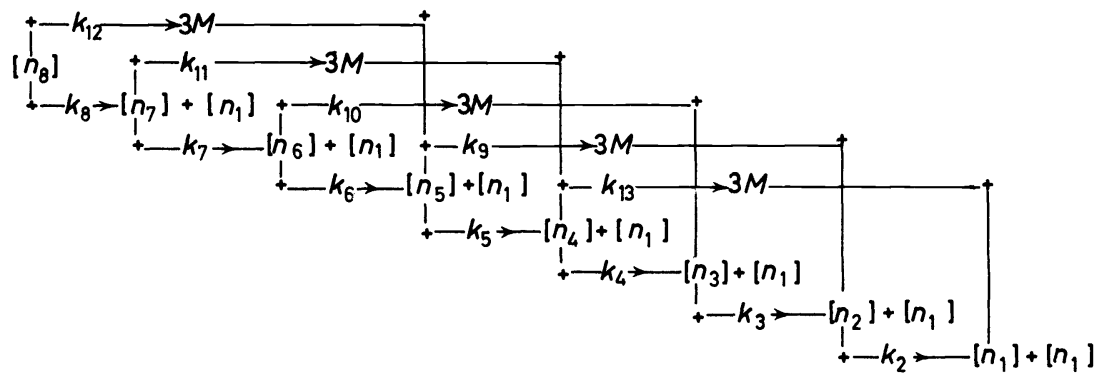

and also

$[3 M]-k_{14}=\left[n_{3}\right]$

The lower route is the progressive decrease of the phosphate chain length by the cleavage of an orthophosphate. Therefore, $k_{8}$ is the rate constant for the formation of orthophosphate and heptaphosphate from octaphosphate, while $k_{7}$ is the rate constant for the formation of orthophosphate and hexaphosphate from heptaphosphate, etc. On the other hand, the upper route is the abstraction of trimetaphosphate from a polyphosphate. Therefore, $k_{12}$ is the rate constant for the abstraction of trimetaphosphate from octaphosphate to form pentaphosphate and trimetaphosphate, while $k_{11}$ is the rate constant for the abstraction of trimetaphosphate from heptaphosphate to form tetraphosphate, etc.

In order to calculate the concentration of each species as a function of time, the following series of simultaneous equations can be derived.

$$
\begin{gathered}
\mathrm{d} C_{1} / \mathrm{d} t=2 k_{2} C_{2}+k_{3} C_{3}+\ldots k_{8} C_{8} \\
\mathrm{~d} C_{2} / \mathrm{d} t=k_{3} C_{3}+k_{9} C_{5}-k_{2} C_{2} \\
\mathrm{~d} C_{3} / \mathrm{d} t=k_{4} C_{4}+k_{10} C_{6}-k_{3} C_{3}+k_{13} C_{3 m} \\
\mathrm{~d} C_{4} / \mathrm{d} t=k_{5} C_{5}+k_{11} C_{7}-k_{4} C_{4} \\
\mathrm{~d} C_{5} / \mathrm{d} t=k_{6} C_{6}+k_{12} C_{8}-k_{5} C_{5}-k_{9} C_{5} \\
\mathrm{~d} C_{6} / \mathrm{d} t=k_{7} C_{7}-k_{6} C_{6}-k_{10} C_{6} \\
\mathrm{~d} C_{7} / \mathrm{d} t=k_{8} C_{8}-k_{7} C_{7}-k_{11} C_{7} \\
\mathrm{~d} C_{8} / \mathrm{d} t=k_{8} C_{8}-k_{12} C_{8} \\
\mathrm{~d} C_{3 m} / \mathrm{d} t=k_{12} C_{8}+k_{11} C_{7}+k_{10} C_{6}+k_{9} C_{5}-k_{13} C_{3 m}
\end{gathered}
$$

The series of simultaneous equations can be solved by the Runge-Kutta method $^{55}$ with the aid of a computer. Most of the rate constants needed 


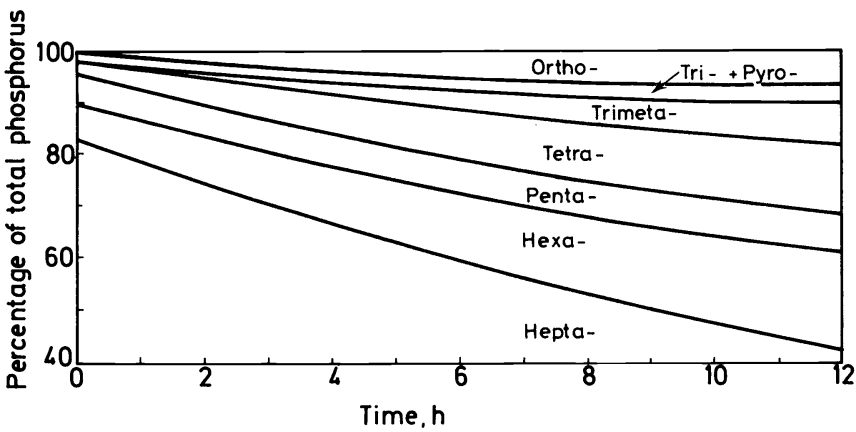

Figure 17. Cleavage family of heptaphosphate at $\mathrm{pH} 7$ and $60^{\circ} \mathrm{C}$ by analysis.

can be obtained from the previously published data ${ }^{23}$ for the degradation of polyphosphates up to octaphosphate. Reasonably good estimates can be made by extrapolation of the data to polyphosphates containing several more phosphorus atoms. The rate constants for tri-, pyro- ${ }^{54}$, and trimetaphosphates are available from other published data ${ }^{56}$. The rate constant for the degradation of trimetaphosphate to triphosphate is an estimate based upon the published literature and may be in error because the conditions were not the same. Since the concentration of trimetaphosphate is usually small during the period presented, this estimate does not introduce an appreciable error in the total curves presented, even if this step is assumed to be very small.

The curves presented in the calculated data require the use of fourteen rate constants and nine concentration terms when applied to octaphosphate. Despite the accumulated errors, the calculated data are probably as nearly correct as the analysed data. Some of the curves obtained by analysis were impossible to interpret reliably and only the best data are presented.

Trimetaphosphate also created difficulties in the separation of chain phosphates on a one-dimensional acidic chromatogram because it was difficult to separate it from penta- and hexaphosphates. For this reason, the trimetaphosphate was determined by a separate two-dimensional chromatogram and analysed separately. The hexa- or penta- data were then corrected

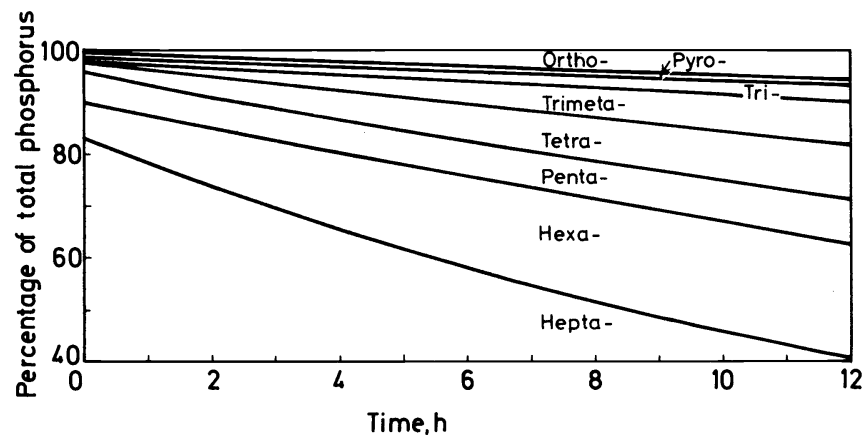

Figure 18. Cleavage family of heptaphosphate at $\mathrm{pH} 7$ and $60^{\circ} \mathrm{C}$ calculated. 


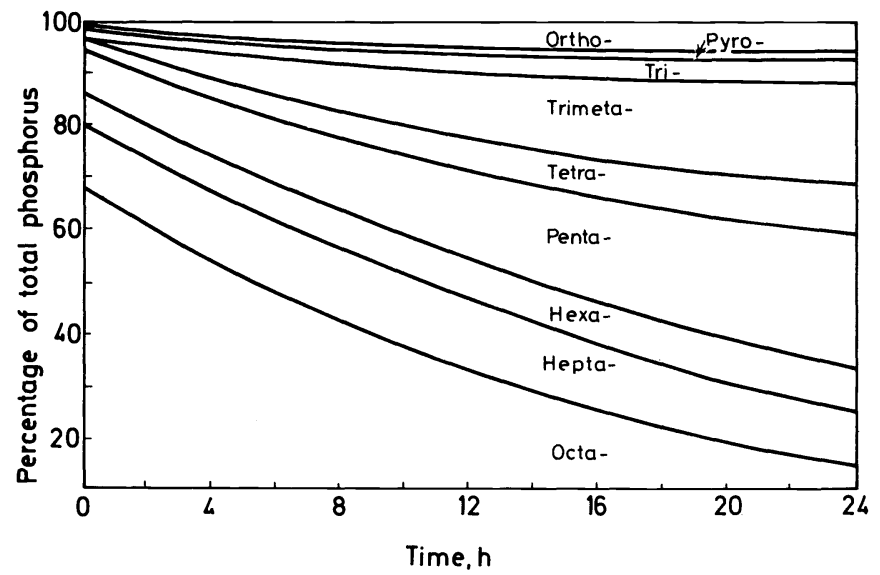

Figure 19. Cleavage family of octaphosphate at $\mathrm{pH} 11$ and $60^{\circ} \mathrm{C}$ by analysis.

to fit the requirements established by the sum of the concentrations of the other phosphates. Obviously the analytical techniques employed were extended to the practical limits of their usefulness and the results were at times frustrating and disappointing.

Several of the figures are worthy of comment. In Figure 3 for the hydrolysis of sodium tetraphosphate, the small quantities of trimetaphosphate which formed during degradation were ignored. There was a definite increase, but the quantity was too small to measure correctly. In Figures 11 through 16 the influence of $\mathrm{pH}$ on the ratio of orthophosphate to trimetaphosphate is clearly seen. The calculated tetraphosphate in Figure 6 is less than the analysed tetraphosphate, while the trimetaphosphate is greater than the analysed system. The rate constant for the degradation of trimetaphosphate at pH 11 and $60^{\circ} \mathrm{C}$ is estimated and this probably contributes to the observed differences.

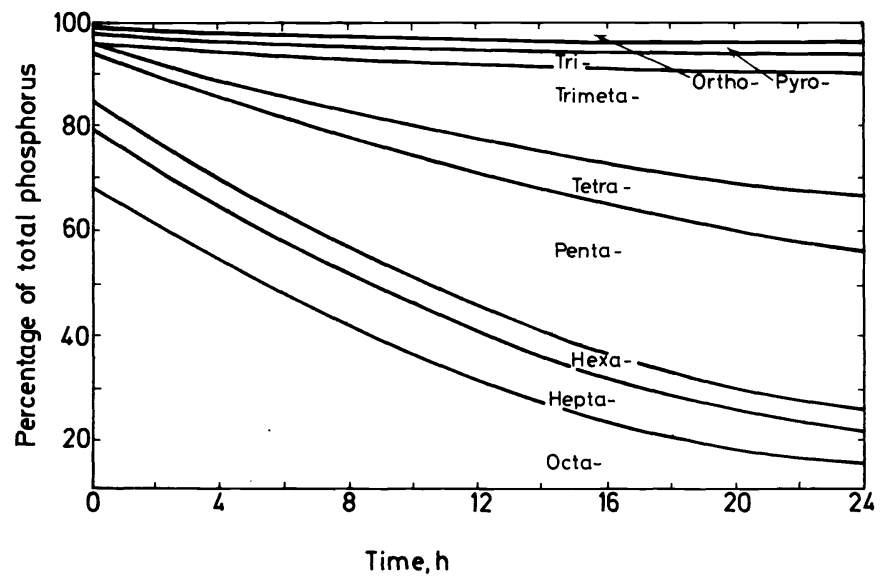

Figure 20. Cleavage family of octaphosphate at $\mathrm{pH} 11$ and $60^{\circ} \mathrm{C}$ calculated. 


\section{EDWARD J. GRIFFITH}

Only one of the octaphosphate families is included because of the difficulties with the interpretation of chromatograms of this complexity. With the more time-consuming analytical techniques, systems of this complexity can be analysed.

\section{CONCLUSION}

In conclusion it can be seen that remarkable progress in both pure and applied phosphate chemistry has been made during the last decade. Only a small fraction of the progress has been noted in this work. The general groundwork has been prepared and the next decade should be one of unparallelled accomplishment.

\section{REFERENCES}

1 J. R. Van Wazer, Phosphorus and Its Compounds, Vols I and II. Interscience: New York (1958).

2 E. Thilo, 'Condensed phosphates and arsenates' in H. J. Emeléus, and A. G. Sharpe, Eds. Inorganic and Radiochemistry, Vol. IV, p 1. Academic Press: New York (1972).

3 D. E. C. Carbridge, 'The structural chemistry of phosphorus compounds' in M. Grayson E. J. Griffiths, Eds. Topics in Phosphoros Chemistry, Vol. VI, p 235 (1969). York (1966).

4 D. E. C. Carbridge, 'The infrared spectra of phosphorus compounds', in M. Grayson and E. J. Griffith, Eds. Topics in Phosphorus Chemistry, Vol. VI, p 235 (1969).

5 S. Ohashi, 'Condensed phosphates centaining other oxo. acid anions', ibid. Vol. I, p 189 (1964).

- M. M. Crutchfield, C. H. Dungan, J. H. Letcher, V. Mark and J. R. Van Wazer, 'Nuclear magnetic resonance', ibid. Vol. V, p 31 (1967).

7 E. Fluck, 'Phosphorus-nitrogen chemistry', ibid. Vol. IV, p 291 (1967).

8 R. K. Osterheld, 'Nonenzymic hydrolysis at phosphate tetrahedra', ibid. Vol. VII, p 103 (1972).

9 S. Y. Kalliney, 'Cyclophosphates', ibid. Vol. VII, p 255 (1972).

10 I. I. Creaser and J. O. Edwards, 'Peroxophosphates', ibid. Vol. VII, p 379 (1972).

11 C. Y. Shen and F. W. Morgan, 'Hydrolysis of phosphorus compounds' in E. J. Griffith, A. Berton, J. M. Spencer and D. T. Mitchell, Eds. Environmental Phosphorus Handbook, p 241. Wiley-Interscience: New York (1973).

12 W. E. Brown, 'Solubilities of phosphate and other sparingly soluble salts', ibid, p 203.

13 W. Chamberlain and J. Shapiro, 'Phosphate measurements in natural waters-A critique', ibid. p 355.

14 A. Durif, Rev. Chim miner. 6, 109 (1969).

$15 \mathrm{M}$. Laügt, 'Etude Des systèmes $\mathrm{M}^{\prime} \mathrm{PO}_{3}-\mathrm{Cu}\left(\mathrm{PO}_{3}\right)_{2}$ avec $\mathrm{M}^{\prime}=\mathrm{Li}, \mathrm{Na}, \mathrm{K}, \mathrm{Rb}, \mathrm{Cs}, \mathrm{Ag}, \mathrm{Tl}$, $\mathrm{NH}_{4}^{+}$. Thése de L'Université de Lyon (1969).

16 E. Thilo and V. Schuelke, Z. Anorg. Allgem. Chem. 341, 293 (1965).

17 E. J. Griffith and R. L. Buxton, Inorg. Chem. 4, 549 (1965).

18 V. Schulke, Z. Anorg. Allgem. Chem. 360, 231 (1968).

19 J. F. Andon, J. F. Caunsell, J. F. Martin and C. F. Marsh, J. Appl. Chem. 17, 65 (1967).

20 R. J. Irving and H. McKerrell, Trans. Faraday Soc. 64, 875 (1968).

21 T. R. Meadowcroft and F. D. Richardson, Trans. Faraday Soc. 59, 1954 (1963).

22 T. Glonek, Diss. Abstr. Int. 30, 3554 (1970).

23 E. J. Griffith and R. L. Buxton, J. Amer. Chem. Soc. 89, 2884 (1967).

24 Y. Veno, N. Yoza and S. Ohashi, J. Chromatogr. 52, 469 (1970).

${ }^{25}$ S. Ohashi and J. R. Van Wazer, Anal. Chem. 35, 1984 (1963).

26 E. J. Griffith and R. L. Buxton, J. Chem. Engng Data, 13, 145 (1968).

27 B. R. Humble and J. L. Copeland, J. Chem. Engng Data, 15, 441 (1970).

28 W. Wieker, H. P. Walter and E. Thilo, Ber. Dtsch. Chem. Ges. 97,2385 (1964).

${ }^{29}$ A. R. Ubbelohde, Quart. Rev. 11, 246 (1957).

30 G. W. Morey and E. Ingerson, Amer. J. Sci. 242, 4 (1944).

31 R. K. Osterheld and R. P. Langguth, J. Phys. Chem. 59, 76 (1955).

32 W. L. Hill, G. T. Faust and D. S. Reynolds, Amer. J. Sci. 242, 469 (1944). 
33 H: Huber, Angew Chem. 50, 323 (1937).

34 H. Grunze and E. Thilo, Z. Anorg. Allgem. Chem. 281, 284 (1955).

35 E. Thilo, I. Grunze and H. Grunze, Mber. Dtsch. Akad. Wiss., Berlin, 1, 40 (1959).

36 R. M. Bell and L. F. Audrith, Industr. Engng Chem. 44, 568 (1952).

37 H. M. Ondik, Acta. Cryst. 16A, 71 (1963).

38 E. J. Griffith, J. Amer. Chem. Soc. 78, 386 (1956).

39 P. Bonneman-Bemia, Ann. Chem. 16, 395 (1941).

40 B. Raestrick, J. Ray. Call. Sci. 19, 9 (1949).

41 E. Thilo and H. Seemann, Z. Anorg. Allgem. Chem. 267, 65 (1951).

42 E. Thilo, SB Dtsch. Akad. Wiss. Berlin, Kl. Math. u. Allgem. Natur. 1952, No. 1.

43 O. Quimby, J. Phys. Chem. 58, 603 (1954).

44 E. J. Griffith, Anal. Chem. 28, 525 (1956).

45 A. C. Zettlemoyer, Ch. H. Schneider, H. V. Anderson and R. J. Fuchs, J. Phys. Chem. 61, 991 (1957).

46 C. Y. Shen, J. Metcalf and E. O'Grady, Industr. Engng Chem. 51, 717 (1959).

47 W. O. Groves and J. W. Edwards, J. Phys. Chem. 65, 645 (1960).

48 P. G. Sears, unpublished data, Monsanto Company.

49 I. Matooka, G. Hashizume and M. Kobayashi, J. Phys. Chem. 73, 3012 (1969).

50 I. Grunze, E. Thilo and H. Grunze, Chem. Ber. 93, 2631 (1960).

51 D. M. Bernhart and W. B. Chess, Anal. Chem. 31, 1026 (1959).

52 A. Jamieson, Ann. Pharm. 59, 350 (1842).

53 G. Von Kmorre, Z. Anorg. Chem. 24, 381 (1900).

54 J. R. Van Wazer, E. J. Griffith and J. F. McCullough, J. Amer. Chem. Soc. 77, 287 (1955).

55 J. B. Scarborough, Numerical Mathematical Analysis, 3rd ed., p 299. The Johns Hopkins Press: Baltimore, Md (1955).

56 E. Thilo and W. Wieker, Z. Anorg. Allgem. Chem. 291, 164 (1957).

57 M. Porthault, Rev. Chim. Minérale, 1, 125 (1964).

58 E. A. Prodan, M. M. Pavlyuchenko, V. A. Sotnikova-Yuzhik, Yu. G. Zonov and L. A. Lesnikovich, Geterogennye Khim. Reaktr. 6 (1970).

59 E. A. Prodan, M. M. Pavlyuchenko, G. V. Peslyak and V. A. Sotnikova-Yuzhik, Dokl. Akad. Nauk SSSR, 200(6), 1369 (1971).

60 V. A. Sotnikova-Yuzhik, E. A. Prodan and M. M. Pavlyuchenko, Dokl. Akad. Nauk SSSR, 199(4), 869 (1971).

61 V. A. Sotnikova-Yuzhik, E. A. Prodan and M. M. Pavlyuchenko, Dokl. Akad. Nauk SSSR, 197(1), 143 (1971).

62 E. A. Prodan, V. A. Sotinkova-Yuzhik and V. A. Pavlynchenko, Dokl. Akad. Nauk SSSR, 15(3), 236(1971).

63 E. A. Prodan, L. A. Lesnikovich and M. M. Pavlyuchenko, Dokl. Akad. Nauk SSSR, 15(9), 813 (1971).

64 M. M. Pavlyuchenko, E. A. Prodan and L. A. Lesnikovich, Dokl. Akad. Nauk SSSR, 16(8), 719 (1972).

65 V. A. Sotnikova-Yuzhik, M. M. Pavlyuchenko and E. A. Prodan, Vestsi Akad. Navuk Belarus. SSR, Ser. Khim. Navuk, No. 1, 14 (1971).

${ }^{66}$ E. A. Prodan, Yu. T. Zonov and M. M. Pavlyuchenko, Vestsi Akad. Navuk Belarus. SSR, Ser. Khim. Navuk, No. 2, 21 (1971).

67 Yu. G. Zonov, E. A. Prodan and M. M. Pavlyuchenko, Vestsi Akad. Navuk Belarus. SSR, Ser. Khim. Navuk, No. 3, 33 (1971).

68 E. A. Prodan and Yu. G. Zonov, Vestsi Akad Navuk Belarus, SSR, Ser. Khim. Navuk, No. 4, 67 (1972).

69 L. A. Lesnikovich, E. A. Prodan, M. M. Pavlyuchenko and G. V. Kunitskaya, Vestsi Akad. Navuk Belarus. SSR, Ser. Khim. Navuk. No. 2, 9 (1972).

70 V. A. Sotnikova-Yuzhik, E. A. Prodan, M. M. Pavlyuchenko and G. V. Iunitskaya, Izvest. Akad. Nauk SSR, Neorg. Mater. No. 7(9), 1539 (1971).

71 E. A. Prodan, M. M. Pavlyuchenko and Yu. G. Zonov, Izvest. Akad. Nauk SSR, Neorg. Mater. No. 8(6), 1090 (1972).

72 E. A. Prodan, M. M. Pavlyuchenko and L. A. Lesnikovich, Izvest. Akad. Nauk SSR, Neorg. Mater, No. 8(1), 106 (1972).

73 E. A. Prodan and Yu. G. Zonov, Zh. Neorg. Khim. No. 17(5), 1220 (1972).

74 E. A. Prodan, V. A. Sotnikova-Yuzhik and M. M. Pavlyuchenko, Zh. Neorg. Khim. No. 17(1), 56 (1972). 
${ }^{75}$ B. M. Beglov, Uzb. Khim. Zh. No. 16(1), 34 (1972).

76 B. M. Beglov, Uzb. Khim. Zh. No. 16(4), 36 (1972).

77 B. B. Luff, R. B. Reed and Z. T. Wakefield, J. Chem. Engng Data, No. 17(1), 96 (1972).

78 B. S. Kogan, Zh. Fiz. Khim. No. 45(6), 1571 (1971).

79 T. Glonek, J. R. Van Wazer, M. Mudgett and T. C. Myers, Inorg. Chem. No. 11(3), 567 (1972)

80 A. B. Bekturov, E. V. Poletaev and Yu. A. Kushnikov, Khim. Tekhnol. Kondens. Fosfatov., Tr. Usec. Soveshch. 146 (1968).

81 U. P. Strauss and J. W. Day, J. Polym. Sci. 16, 2161 (1967).

${ }^{82}$ L. V. Kubasova, Usp. Khim. No. 4(1), 3 (1971).

83 L. Boulle, Colloq. Nat., Centre Nat. Rech. Sci. 279 (1965).

84 E. Kobayashi, Kogyo Kagaku Zasshi, 71, 807 (1968).

85 M. Averbuch-Pouchot and A. Durif, Mater. Res. Bull. 4, 397 (1969).

${ }^{86}$ M. Averbuch-Pouchot, CR Acad. Sci., Paris, 269, 26 (1969).

87 A. Mermet, M. Averbuch-Pouchot and A. Durif, Bull. Soc. Fr. Minéral. Cristallogr. 92 , 87 (1969).

88 Y. Henry and A. Durif, Bull. Soc. Fr. Minéral. Cristallogr. 92, 484 (1969).

89 C. Martin and A. Durif, Bull. Soc. Fr. Minéral. Cristallogr. 92, 489 (1969).

90 M. T. Averbuch-Pouchot and A. Durif, Mater. Res. Bull. 4, 859 (1969).

91 E. Rakotomahanina-Rolaisoa, Y. Henry, A. Durif and C. Raholison, Bull. Soc. Fr. Minéral. Cristallogr. 93, 43 (1970).

92 J. C. Grenier, C. Martin and A. Durif, Bull. Soc. Fr. Minéral. Cristollogr. 93, 52 (1970).

93 M. T. Averbuch-Pouchot and M. E. Rakotomakanina-Ralaisoa, Bull. Soc. Fr. Minéral. Cristalogr. 93, 394 (1970).

94 Y. Henry and A. Durif, CR Acad. Sci., Paris, 270, 423 (1970).

95 M. Bagieu-Beucher and A. Durif, Bull. Soc. Fr. Minéral. Cristallogr. 94, 440 (1971).

96 J. C. Grenier and I. Mahama, CR Acad. Sci., Paris, 274, 1063 (1972).

97 C. Raholis on and M. T. Averbuch-Pouchot, CR Acad. Sci., Paris, 274, 1066 (1972).

98 C. Martin and A. Durif, Bull. Soc. Fr. Minéral. Cristallogr. 95, 149 (1972).

99 E. Rakotomahanina-Ralaisoa, Bull. Soc. Fr. Minéral. Cristallogr. 95, 143 (1972).

100 J. C. Grenier and A. Durif, Rev. Chim. Minér. 9, 351 (1972).

M. J. Averbuch-Pouchot and A. Durif, J. Appl. Crystallogr. 5, 307 (1972).

102 M. J. Averbuch-Pouchot and A. Durif, Z. Kristallogr., Kristallgeno., Kristallphys., Kristall-

101 chem. 135, 318 (1972).

103 I. V. Mardirosova and G. A. Bukhalova, Zh. Neorg. Khim. 11, 2378 (1966).

104 E. L. Krivovyazov, K. K. Palkina and N. K. Voskresenskaya, Dokl. Akad. Nauk SSSR, 174, 610 (1967).

105 D. Z. Serazetdinov, A. D. Kruchinina and E. V. Poletaev, Khim. Technol. Kondens. Fosfator, Tr. Vses. Soveshch. (Ed. D. Z. Serazetdinov), 30 (1968).

106 S. I. Volfkovich, T. D. Pozharskaya and L. V. Kubasova, Dokl. Akad. Nauk SSSR, 193, $583(1971)$.

107 E. L. Krivovyazov, V. P. Volkova and N. K. Voskresenskaya, Izvest. Akad. Nauk SSSR, Neorg. Mater. 6, 761 (1970).

108 A. D. Kruchinina and D. Z. Serazetdinov, Izvest. Akad. Nauk Kaz. SSR, Ser. Khim. 21, 1 (1971).

109 E. L. Krivovyazov, N. K. Voskresenskaya, L. L. Shutyi and B. B. Dzhurinskii, Izvest. Akad. Nauk SSSR, Neorg. Mater. 8, 1280 (1972).

110 S. M. Aiken and J. B. Gill, J. Inorg. Nucl. Chem. 28, 2460 (1966).

111 I. Matooka, M. Ishizaki, H. Nozu and M. Kobayashi, Kogyo Kagaku Zasshi, 69, 2071 (1966).

112 I. Matooka, Y. Endo, M. Marikawa, M. Ishizaki and M. Kobayashi, Kogyo Kagaku Zasshi. 70, 1097 (1967).

113 J. B. Gill and S. A. Riaz, J. Chem. Soc. A, 843.(1969).

114 T. C. Myers, T. Glonek, P. Z. Han and J. R. Van Wazer, J. Amer. Chem. Soc. 92, 7214 (1970).

115 V. V. Gerasimov, L. I. Kuznetsov-Fetisov, E. V. Kuznetsov and T. B. Skakhmina, Izvest. Akad. Nauk SSSR, Neorg. Mater. 5, 1062 (1969).

116 A. I. Soklakov, N. L. Portnova and V. V. Nechaeva, Khim. Technol. Kondens. Fosfatov, Tr. V ses. Soveshch. (Ed. D. Z. Serazetdinov) 17 (1968). 